\title{
Campanian to Palaeocene biostratigraphy and palaeoenvironments in the Foula Sub-basin, west of the Shetland Islands, UK
}

\author{
T. J. H. A. VAN DEN AKKER ${ }^{1}$, M. A. KAMINSKI ${ }^{1}$, F. M. GRADSTEIN ${ }^{2} \&$ J. WOOD ${ }^{3}$ \\ ${ }^{1}$ Postgraduate Unit of Micropalaeontology, Research School of Geological and Geophysical Sciences, Birkbeck College and University College \\ London, Gower Street, London WC1E 6BT, UK \\ ${ }^{2}$ Saga Petroleum, Kjørboveien 16, N-1301 Sandvika, Norway. (Present address: Måneveien 38, N-1337, Sandvika, Norway) \\ ${ }^{3}$ Saga Petroleum UK, 150 Victoria Street, London, SWIE 5LB, UK
}

\begin{abstract}
For a detailed biostratigraphic framework of the Foula Sub-basin, located west of the Shetland Islands (UK continental shelf), well $205 / 10-2 B$ is chosen as a reference section. Based on the succession of last occurrence events of nominate taxa, ten stratigraphically distinct Campanian to Palaeocene assemblages are described. The regional applicability of these events is tested by correlation between three wells in the Foula Sub-basin (wells 205/10-2B, 206/3-1 and 206/5-1). Despite some local differences, the biostratigraphy of the Foula Sub-basin compares well with the biostratigraphy of the Western Tethys and the northern North Sea, and is therefore an important link between the southern and northern areas of the Northeast Atlantic margin. A morphogroup analysis of agglutinating foraminifera in well 205/10-2B indicates deposition of Campanian and Maastrichtian mudstones in a well oxygenated, lower bathyal environment, whereas Palaeocene sediments are deposited in a middle to upper bathyal environment. J. Micropalaeontol. 19(1): 23-43, May 2000
\end{abstract}

\section{INTRODUCTION}

The Faeroe-Shetland Basin is a deep asymmetric half-graben, situated on the North Atlantic margin, west of the Shetland Islands (Fig. 1). The basin was a major Cretaceous depocentre where thick successions of turbidite-derived mudstones from the Upper Cretaceous Shetland Group accumulated.

The oil industry has shown great interest in the area west of the Shetland Islands due to the discovery of a number of gas and oil fields in the Faeroe-Shetland Basin. As a result, a large number of exploration wells have been drilled in the area, many of which are now released. Despite the need for a good biostratigraphic framework to date the monotonous successions of mudstones of the Upper Cretaceous Shetland Group, no biozonation scheme for the area west of the Shetland Islands has yet been published. However, Ritchie et al. (1996) and Knox et al. (1997) have described some faunal events found in the area, which may form the basis for a zonation scheme. These events correlate well with those described by King (1989) and King et al. (1989) in their zonation schemes for the northern North Sea (Viking Graben and adjacent areas).

Besides the hydrocarbon potential, the Faeroe Shetland Basin is a very important sea-way linking the North Atlantic and Arctic Oceans. Study of the microfossil assemblages in this basin is important for reconstructing the palaeoceanographic circulation between the North Atlantic and Arctic oceans.

Therefore, the main objective of this study is to define a Campanian - Palaeocene biostratigraphic zonation scheme for a sub-basin of the Faeroe-Shetland Basin, the Foula Sub-basin. In addition to biostratigraphy, the record of microfaunal assemblages is also a useful tool to give insight in the palaeobathymetric and palaeoenvironmental history of the Foula Sub-basin.

Well 205/10-2B is chosen as a reference section for a detailed biostratigraphic framework in the Foula Sub-basin because of the (almost $1070 \mathrm{~m}$ ) thick succession of Campanian and Maastrichtian sediments present. The biostratigraphy of well

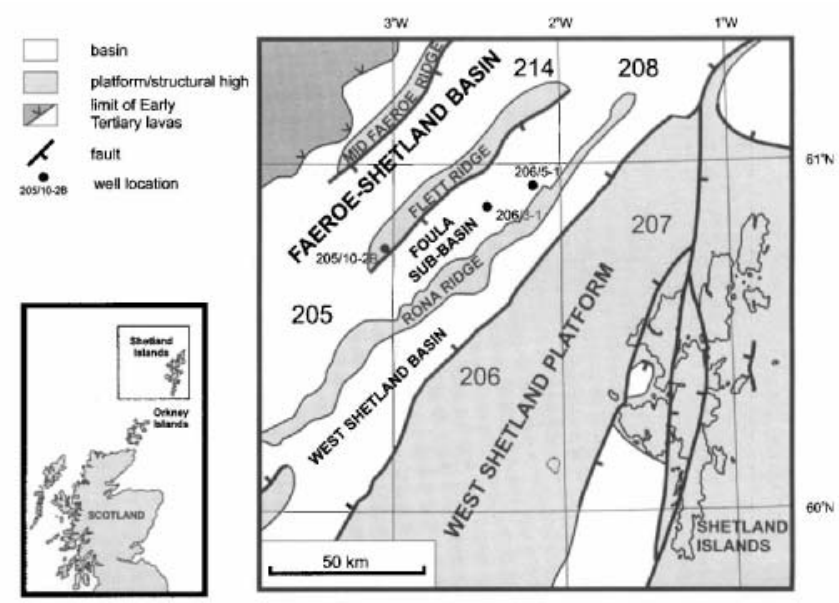

Fig. 1. Location map and detail of Pre-Tertiary structure of the area west of the Shetland Islands (after Ritchie et al., 1996).

205/10-2B is compared with data from two other wells in the Foula Sub-basin: 206/3-1 and 206/5-1 (see Fig. 1 for location).

\section{STUDY AREA}

\section{Geological setting}

The Faeroe Basin, which was the location of a major Cretaceous depocentre, is a deep asymmetric half-graben between the Rona Ridge and the Mid-Faeroe Ridge (Fig. 1). The graben between the Rona Ridge and the Flett Ridge is referred to as the Foula Sub-basin. The ridges are intrabasinal basement features, blanketed by thick sequences of Cretaceous to Recent sediments. The development of the basin is strongly related to the opening history of the North Atlantic and experienced its major extension during the Cretaceous. Extensive reviews of the basin structural and stratigraphic development have been given by 


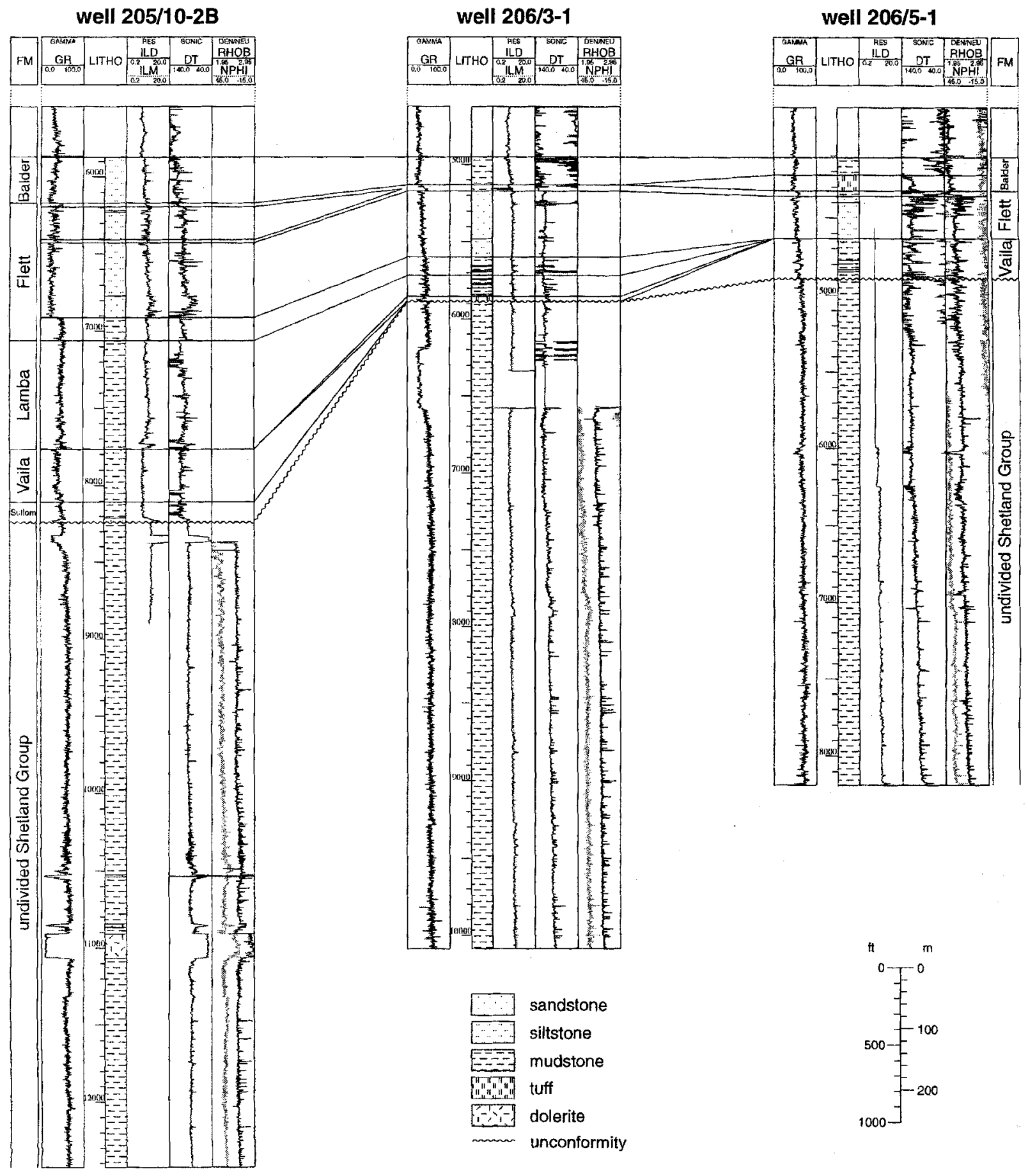

Fig. 2. Lithostratigraphic correlation of three wells in the Foula Sub-basin. Given depths are in feet.

Duindam \& van Hoorn (1987), Hitchen \& Ritchie (1987), Mudge \& Rashid (1987), Earle et al. (1989) and Turner \& Scrutton (1993), and only a short summary is given here.

Basin development in the Faeroe-Shetland area commenced in Devonian times, although extension was minor. In the West Shetland Basin, sequences of Devonian to Lower Carboniferous aeolian and fluvial beds occur, hosting the Clair oil field on the Rona Ridge (Ridd, 1981). Uplift and erosion during the Late Carboniferous resulted in widespread erosion. A second cycle of rifting and subsidence occurred during Permian to Early Triassic times, with deposition taking place primarily in continental settings. Pre-rift doming in the Late Triassic to Early Jurassic 
period resulted in erosion, before a global marine transgression invaded the area and the first shallow marine sediments of Middle to Late Jurassic age were deposited (Ridd, 1981). Extension continued during the Late Jurassic, although the occurrence of a widespread unconformity at the base of the Cretaceous sequence indicates that basement highs were subjected to uplift and erosion.

The main episode of rifting in the area commenced in Early Cretaceous times with the onset of intensive extension in the Rockall Trough as part of the major North Atlantic sea floor spreading system developing between Greenland and Europe. The Faeroe Basin is regarded as the northern continuation of the Rockall Trough, and its rifting history is strongly related to its opening. The Rockall Trough rift failed in Santonian times (Megson, 1987), leaving the area subjected to thermal subsidence. A distinct pulse of mid-Campanian faulting and associated footwall uplift resulted in a hiatus over the structurally highest parts of the Rona Ridge (Ridd, 1981). Renewed (thermal) extension developed, but was interrupted during the Palaeocene and early Eocene periods by thermal doming associated with the Icelandic mantle plume, which was centred over East Greenland by that time (Ebdon et al., 1995; Nadin et al., 1997). The thermal uplift was accompanied by voluminous subaerial volcanism (Thulean phase) north of the Faeroe Islands (Chalmers et al., 1995); effusive volcanism was succeeded by a final phase of explosive volcanism (Roberts et al., 1984). Due to the regional uplift, extensional faulting developed in the area west of the Shetland Islands, resulting in erosion on the West Shetland margin and deposition of submarine fans in the accelerated subsiding Faeroe Basin. The thermal dome collapsed in the early Eocene with the onset of sea floor spreading between Greenland and Northwest Europe (Roberts et al., 1984; Chalmers et al., 1995). Since this event, the basin has continued to subside.

\section{Lithostratigraphic framework}

The Mesozoic and Cenozoic lithostratigraphy of the area west of the Shetland Islands has been recently revised by Ritchie et al. (1996) and Knox et al. (1997). Based on well log character and transitions, formations are differentiated in the Shetland Group (Kyrre, Jorsalfare and Sullom Formations), Faeroe Group (Vaila and Lamba Formations) and the Moray Group (Flett and Balder Formations). The Shetland Group is a succession of pale grey to dark grey calcareous and non-calcareous mudstones and is laterally equivalent to the Chalk Group in the Central and Southern North Sea. In the Foula Sub-basin, it is difficult to identify formation boundaries in the monotonous succession of Campanian and Maastrichtian mudstones, and therefore the Shetland Group is undivided (see Fig. 2).

The Maastrichtian calcareous mudstones are unconformably overlain by sediments of the Sullom Formation (lower Palaeocene), Vaila Formation and Kettla Member of the Lamba Formation (upper Palaeocene) (see Fig. 2). This basal Palaeocene unconformity is indicated by a downhole increase in gamma-ray values and decrease in velocity. Due to thermally induced uplift in the early Palaeocene (Ebdon et al., 1995; Nadin et al., 1997), the area was subjected to erosion, resulting in a stratigraphic gap encompassing the uppermost Maastrichtian and Lower to Upper Palaeocene sediments. In well 205/10-2B the Maastrichtian sediments are overlain by calcareous mudstones of the Sullom Formation, deposited during late early Palaeocene times. The upper boundary of the Sullom Formation with the silty calcareous mudstones of the Vaila Formation (Upper Palaeocene) is taken at a downhole increase in the gamma-ray response. The presence of the lower unit of the Vaila Formation (V1) in well 205/10-2B is indicated by the recovery of abundant Cenosphaera lenticularis (Grzybowski, 1896) at 8060 feet $(2457 \mathrm{~m})$, just above the upper boundary of the Sullom Formation (Ritchie et al., 1996). The medium to dark grey silty calcareous mudstones of the Vaila Formation are characterized by relatively low gamma-ray values. In more basinal sections, the Vaila Formation contains thick sandstone units; however, in well 206/5-1 only thin sandstone layers are present.

In places where the tuffaceous siltstones of the Kettla Member in the base of the Lamba Formation are absent (characterized by low gamma-ray values and a high velocity; see well 206/3-1 in Fig. 2), the upper boundary of the Vaila Formation with the light to medium grey mudstones of the Lamba Formation is distinctive by the downhole increase in gamma-ray values. In well 206/5-1 the Lamba Formation is absent and the Flett Formation rests unconformably on the Vaila Formation. The distinction between the variegated sediments of the Flett Formation and the more uniform mudstones of the Lamba Formation is not very well defined, and is taken here at a downhole increase in gamma-ray response. In the Flett Formation two sandstone members are recognized: a thick and geographically widespread unit of Upper Colsay sandstones and, on top of that, separated by a persistent layer of mudstones, the more restricted Hildasay sandstones. Both units are dominated by progradational and aggradational shallow marine mudstones and sandstones. The top of the Flett Formation is marked by a downhole increase in gamma-ray values, indicating the change from silty mudstones rich in tuff (from the Balder Formation) to darker grey mudstones containing fewer tuffs. The tuffs of the Balder Formation are believed to have been derived from the late phase of the Thulean volcanism in the Greenland-Faeroe area (Chalmers et al., 1995) and are of early Eocene age (Earle et al., 1989). The upper boundary of the Balder Formation is identified by a downhole decrease in gamma-ray values and increasing velocity. The tuff is not recorded in every well, because it is masked by the normal terrigenous sedimentation.

The deepening of the basin towards well $205 / 10-2 \mathrm{~B}$ is evident from the thickness of the Palaeocene sedimentary successions in the three wells and from seismic data (Mudge \& Rashid, 1987), indicating that the depocentre of the Palaeocene FaeroeShetland Basin was located NW of the Foula Sub-basin.

\section{MATERIAL AND METHODS}

Ditch cutting samples from the three studied wells were provided by the Department of Trade and Industry (DTI) Core Facility in Edinburgh. The reference well 205/10-2B was drilled in 1984 at $60^{\circ} 5^{\prime} 43.235^{\prime \prime} \mathrm{N}$ and $03^{\circ} 03^{\prime} 21.812^{\prime \prime} \mathrm{W}$ in $447.5 \mathrm{~m}$ of water, with Britoil plc as the operator. Well 206/3-1 (Amoco, UK) was also drilled during 1984 at $60^{\circ} 52^{\prime} 42.092^{\prime \prime} \mathrm{N}$ and $02^{\circ} 26^{\prime} 23.734^{\prime \prime} \mathrm{W}$ in a water depth of $290.8 \mathrm{~m}$, while well 206/5-1 (Shell, UK) was drilled during 1976 at $60^{\circ} 50^{\prime} 25.98^{\prime \prime} \mathrm{N}$ and $02^{\circ} 10^{\prime} 14.26^{\prime \prime} \mathrm{W}$ in a 


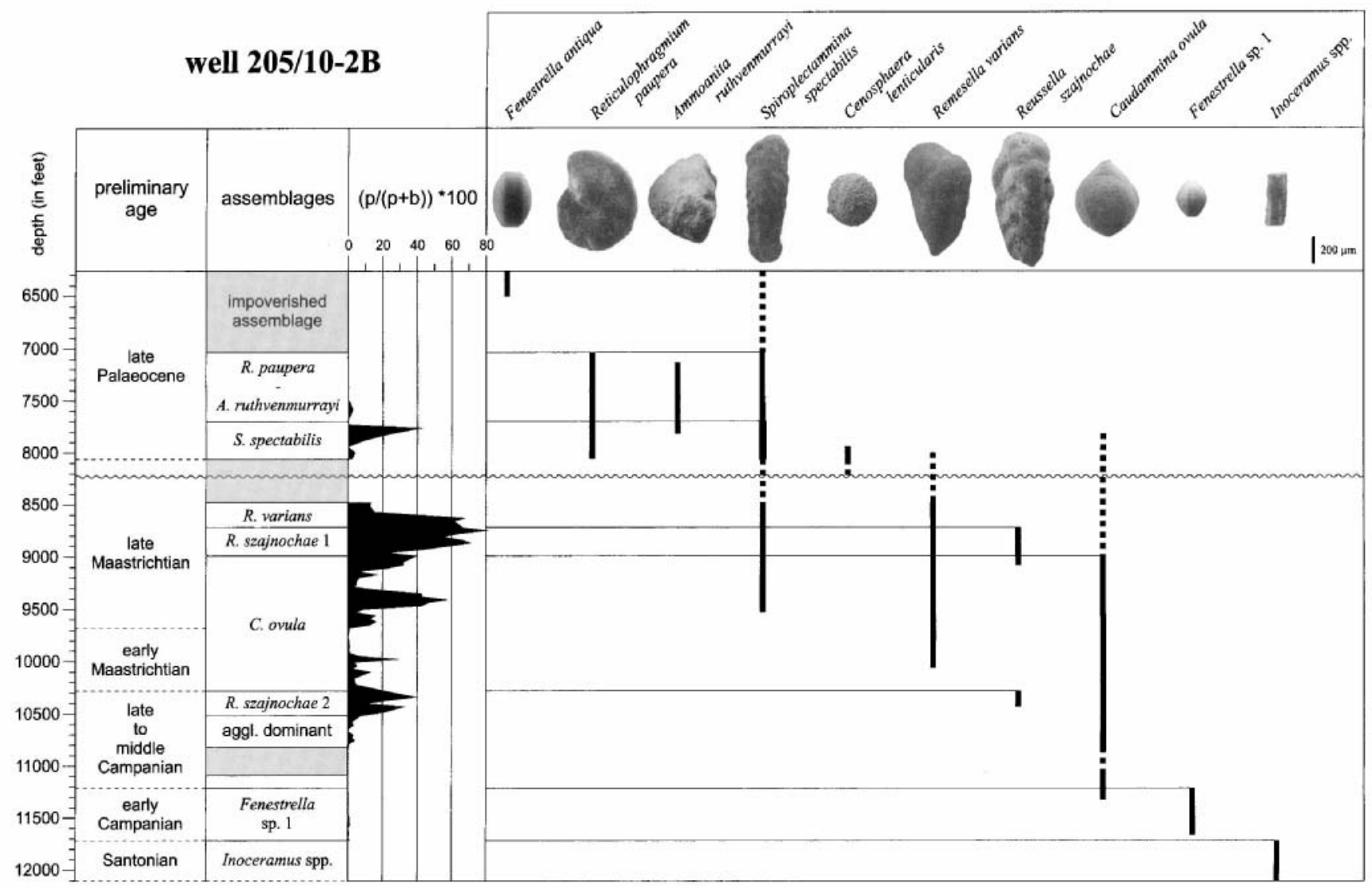

Fig. 3. Chronostratigraphy and distribution of index taxa in well 205/10-2B.

water depth of $284.4 \mathrm{~m}$. All depths of the samples are reported in feet below rotary kelly bushing (which is 1540 feet $(469 \mathrm{~m})$ above the seabed for well $205 / 10-2 \mathrm{~B}$, whereas it is 1044 feet $(318 \mathrm{~m})$ and 1018 feet $(310 \mathrm{~m})$ for wells $206 / 3-1$ and $206 / 5-1$ respectively). The samples, ranging in dry weight from 33 to $77 \mathrm{~g}$, were disintegrated in boiling sodium carbonate solution and washed over a $63 \mu \mathrm{m}$ sieve. Foraminifera, radiolarians and diatoms were picked from the $>125 \mu \mathrm{m}$ fraction and mounted on cardboard slides. Altogether, 124 samples of well $205 / 10-2 B$ were examined, most of them spaced at a 30 feet $(9.1 \mathrm{~m})$ interval. Because an $18^{3} / 8$ inches $(476 \mathrm{~mm})$ casing is placed at a depth of 8349 feet $(2545 \mathrm{~m})$, no samples were available for the interval near the casing (8060-8420 feet, 2457-2566 m). Due to the occurrence of dolerite dykes in the lower part of the studied section, samples from $10280-11060$ feet $(3133-3371 \mathrm{~m})$ are excluded from the analysis. In the samples a total of 153 agglutinating species (including taxa in open nomenclature) were recognized (see Appendix). Estimating the abundance of agglutinating foraminifera is complicated by the fact that many tubular and uniserial rectilinear taxa are recovered only as fragments. Therefore, to describe the faunal assemblages as accurately as possible, every specimen and all identifiable fragments (including calcareous benthic and planktonic taxa for consistency) were counted, although this might result in some duplication. The distribution of the microfossils in well $205 / 10-2 \mathrm{~B}$ is given in order of first downhole appearance in the Appendix.

\section{RESULTS}

\section{Microfossil assemblages}

The Campanian-Palaeocene succession of benthic and planktonic foraminifera, diatoms and radiolarians in well 205/10-2B can be subdivided into ten stratigraphically distinct assemblages, mainly based on the last uphole occurrence events of stratigraphically important agglutinated species (see Fig. 3 and Plate 1) and abundances of other dominant taxa. The chronostratigraphy is based on events reported from the northern North Sea (King, 1989; King et al., 1989; Mudge \& Copestake, 1992; Gradstein et al., 1994; Gradstein \& Bäckström, 1996), the area west of the Shetland Islands (Ritchie et al., 1996; Knox et al., 1997) and from the Norwegian margin (Gradstein, personal observations). In addition to the stratigraphically important taxa, the tubular taxa (Rhabdammina spp. and Rhizammina spp.) are dominant throughout the studied section. Furthermore, Palaeocene assemblages are characterized by abundant Haplophragmoides spp., trochamminids, Karrerulina spp., Cribrostomoides spp. and Recurvoides spp. Throughout the Campanian and Maastrichtian, Psammosphaera spp. and Saccammina spp. are abundant, with common calcareous benthic and planktonic foraminifera down to a depth of 10520 feet $(3206 \mathrm{~m})$. Pyritised moulds of diatoms and radiolarians are common throughout the studied section, while the Lower Campanian is characterized by high abundances of them. Only last uphole occurrence (LO) events are reliable, as we are dealing with ditch cuttings in this 


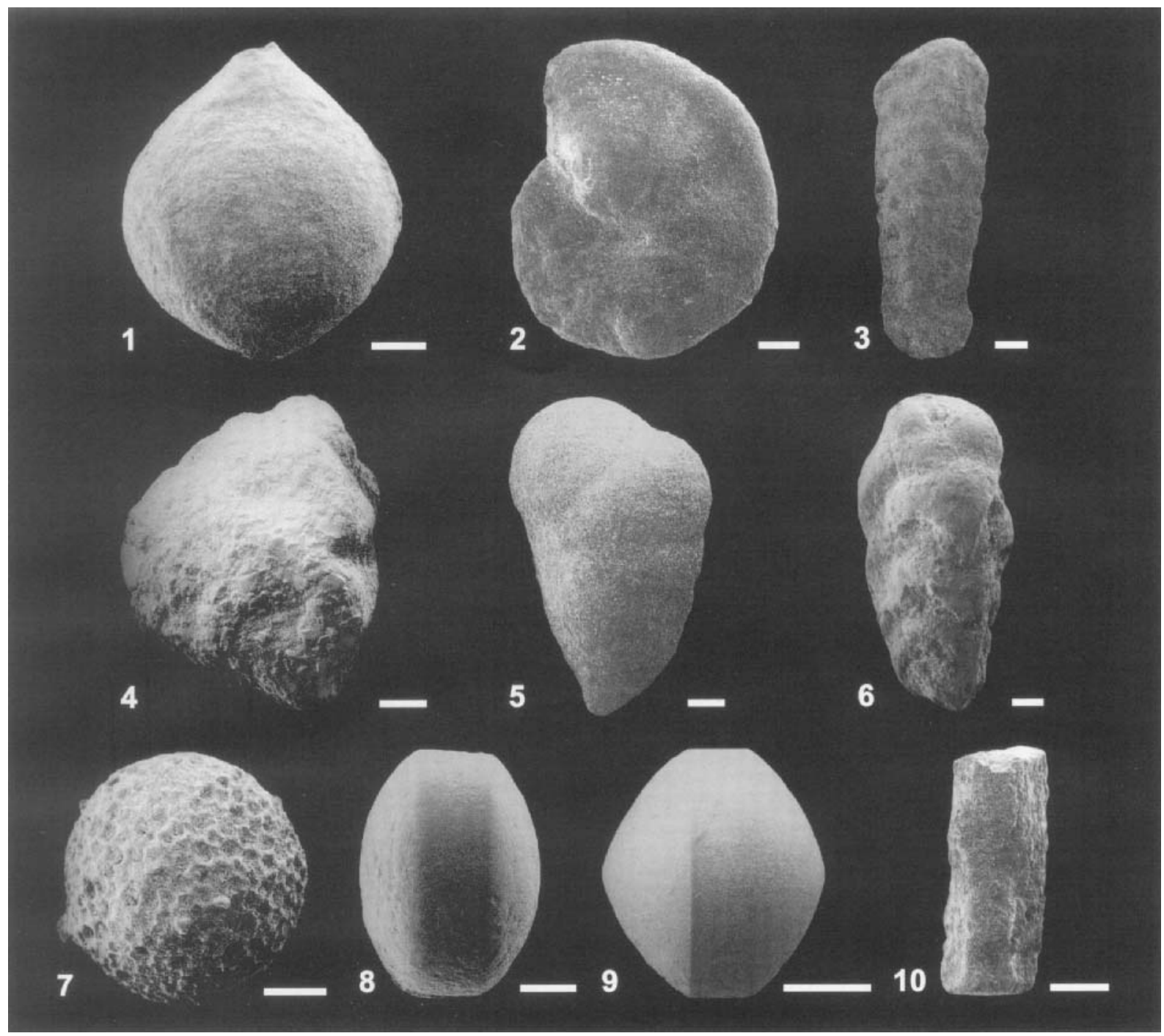

Explanation of Plate 1.

Stratigraphically important microfossils from well 205/10-2B. Horizontal bar is $100 \mu \mathrm{m}$. fig. 1. Caudammina ovula (Grzybowski), $9800 \mathrm{ft}$ ( $2987 \mathrm{~m}$ ), $\times$ 414. fig. 2. Reticulophragmium paupera (Chapman), $7220 \mathrm{ft}(2201 \mathrm{~m}), \times 319$. fig. 3. Spiroplectammina spectabilis (Grzybowski), $7310 \mathrm{ft}(2228 \mathrm{~m})$, $\times 250$. fig. 4. Ammoanita ruthvenmurrayi (Cushman \& Renz), $7220 \mathrm{ft}(2201 \mathrm{~m}), \times 366$. fig. 5 . Remesella varians $(\mathrm{Glaessner}), 10040 \mathrm{ft}(3060 \mathrm{~m}), \times 291$. fig. 6. Reussella szajnochae (Grzybowski), $8930 \mathrm{ft}(2722 \mathrm{~m}), \times 241$. fig. 7 . Cenosphaera lenticularis (Grzybowski), $8060 \mathrm{ft}(2457 \mathrm{~m}), \times 491 . \mathrm{fig} .8$. Fenestrella antiqua (Grunow), $6290 \mathrm{ft}(1917 \mathrm{~m}), \times 449$. fig. 9. Fenestrella sp. 1, $9770 \mathrm{ft}(2978 \mathrm{~m}), \times 678$. fig. 10. Inoceramus spp. needle, $11720 \mathrm{ft}$ $(3572 \mathrm{~m}), \times 466$.

study; therefore, the succession of assemblages will be discussed in order from youngest to oldest.

\section{Impoverished assemblage}

Interval: 6260-7100 feet (1908-2164 m)

Age: latest part of late Palaeocene

Samples examined from this interval were almost barren of foraminifera. This interval spanned a period with locally high input of terrigenous material which has significantly reduced the faunal record in the sediments. Sparse occurrences of Spiroplectammina spectabilis (Grzybowski, 1898), Rhabdammina robusta (Grzybowski, 1898) and Reticulophragmium sp. aff. amplectens (Grzybowski, 1898) are recorded, with abundant small reticulate Cenosphaera spp. In the top samples of this interval, a few large, pillbox shaped pyritized moulds of the diatom Fenestrella antiqua (Grunow, 1882) are recorded. High abundances of these diatoms are characteristic of the lower Eocene Balder Formation (King, 1989; Gradstein et al., 1994; Mudge \& Bujak, 1996; Knox et al., 1997). Therefore, the low abundance of this diatom in this interval, combined with the lithology characteristics, indicates a late Palaeocene age.

\section{Reticulophragmium paupera-Ammoanita ruthvenmurrayi as- semblage}

Interval: $7100-7700$ feet $(2164-2347 \mathrm{~m})$

Age: middle part of late Palaeocene

The last uphole occurrences (LOs) of many taxa are observed 
near the top of this interval, including that of Reticulophragmium paupera (Chapman, 1904), Ammoanita ruthvenmurrayi (Cushman \& Renz, 1946) and the last common occurrence (LCO) of Spiroplectammina spectabilis (see Fig. 3 and Appendix). In the northern North Sea, the LOs of these taxa mark the 'T. ruthvenmurrayi-R. paupera' Zone of Gradstein et al. (1988), which is equivalent to Zone NSAlb of King (1989). In the RASC zonal model of Gradstein \& Bäckström (1996), this interval correlates with Zone NSR2 (late Palaeocene). In the area west of the Shetland Islands, Knox et al. (1997) report in the top of the Lamba Formation (Upper Palaeocene) the LO of a low diversity fauna with $S$. spectabilis. Stratigraphically just below this event, they report a high-diversity agglutinating fauna, which might correlate with the extremely abundant (more than 30 specimens per studied gram) and diverse interval observed in well 205/10-2B (7130-7220 feet, 2173-2201 m). The assemblage also contains common Rhabdammina spp., Rhizammina spp., Haplophragmoides spp., Karrerulina spp., Glomospira spp., Trochammina spp., Budashevaella multicamerata (Voloshinova \& Budasheva, 1961), Cribrostomoides spp. and Recurvoides spp.

\section{Spiroplectammina spectabilis assemblage}

Interval: $7700-8060$ feet (2347-2457 m)

Age: early part of late Palaeocene

The last abundant occurrence (LAO) of Spiroplectammina spectabilis marks the top boundary of this interval. This event should not be confused with the high-abundance and highdiversity event in the previous interval where $S$. spectabilis is also fairly common, although in lower relative proportions (typically less than $4 \%$ of the total fauna). The $S$. spectabilis assemblage is characterized by a less diverse and less abundant foraminiferal fauna (less than seven specimens per gram) with high relative proportions of $S$. spectabilis ( $7-20 \%$ of the total fauna) and common Rhabdammina spp., Rhizammina spp., Haplophragmoides spp., Karrerulina spp., Glomospira spp., Trochammina spp., B. multicamerata, Cribrostomoides spp., Recurvoides spp. and $R$. paupera. This interval correlates with Zone NSAla of King (1989). High abundances of $S$. spectabilis are also recorded from the middle part of the Upper Palaeocene of the western Barents Sea by Nagy et al. (1997). Large reticulate spherical radiolarians, Cenosphaera lenticularis, occur in the base of this interval. These are reported from the lower part of the upper Palaeocene sediments in the North Sea (Jones, 1988; Zone NSP2 of King, 1989; Mudge \& Copestake, 1992; Unit 1 of the Vaila Formation, Knox et al., 1997). In this interval reworked Late Cretaceous planktonic foraminifera also occur in well 205/102B. However, the observation of Parasubbotina pseudobulloides (Plummer, 1927) and Subbotina triloculinoides (Plummer, 1926) confirms the Palaeocene age of this interval (Toumarkine \& Luterbacher, 1985; Berggren \& Norris, 1997).

\section{Remesella varians assemblage}

Interval: $8480-8720$ feet $(2585-2658 \mathrm{~m})$

Age: late Maastrichtian

A distinct change in the composition of the faunal assemblages is observed across the Palaeocene/Cretaceous unconformity (at
8223 feet, $2506 \mathrm{~m}$ ). The assemblage now consists mainly of Rhabdammina spp., Rhizammina spp., Saccammina spp., Psammosphaera spp., calcareous benthic and planktonic species. The common to abundant planktonic taxa include Heterohelix globulosa (Ehrenberg, 1840), Heterohelix planata (Cushman, 1938), Laeviheterohelix dentata (Stenestad, 1968), Laeviheterohelix glabrans (Cushman, 1938), Globigerinelloides volutus (White, 1928), Globotruncanella petaloidea (Gandolfi, 1955), Archaeoglobigerina blowi (Pessagno, 1967), and Hedbergella holmdelensis (Olsson, 1964). The consistent occurrence of Remesella varians (Glaessner, 1937) below the unconformity makes it the nominate taxon of this interval. Because of the absence of Pseudotextularia elegans (Rzehak, 1891) in this assemblage, this interval probably correlates best with the FCN21a Zone of King et al. (1989). In the Northeast Atlantic, the $R$. varians Zone is a useful indicator for the late Maastrichtian (Kuhnt et al., 1992; Kuhnt \& Kaminski, 1997).

\section{Reussella szajnochae 1 assemblage}

Interval: $8720-8990$ feet $(2658-2740 \mathrm{~m})$

Age: late Maastrichtian

This interval is confined between the LO event of Reussella szajnochae (Grzybowski, 1896) and LCO event of Caudammina ovula (Grzybowski, 1896). It is distinguished from the interval above by the occurrences of both $R$. varians and $R$. szajnochae. The microfauna is dominated by abundant planktonic foraminifera, of which the main contributors are $H$. globulosa, $G$. volutus and Archaeoglobigerina spp. The assemblage also contains common Rhabdammina spp., Rhizammina spp., Saccammina spp., Psammosphaera spp., and calcareous benthic and planktonic species. The LO of the calcareous benthic species $R$. szajnochae is reported from the late Maastrichtian (Zone FCN20d of King et al., 1989; Ritchie et al., 1996). This late Maastrichtian age is confirmed by the occurrence of Abathomphalus mayaroensis (Bolli, 1951) in this interval (Caron, 1985; King et al., 1989).

\section{Caudammina ovula assemblage}

Interval: $8990-10280$ feet $(2740-3133 \mathrm{~m})$

Age: early-late Maastrichtian

This assemblage is characterized by the presence of Caudammina ovula. Most of the specimens in the studied samples are assigned to $C$. ovula, rather than to the larger species known as $C$. gigantea (Geroch, 1960). In this interval a four-fold subdivision can be made based on the abundance of calcareous benthic and planktonic foraminifera. The record of calcareous benthic foraminifera shows the same trend in abundances as the planktonic foraminiferal record. Therefore, the peaks in the $(p /(p+b))$-ratios indicate intervals with abundant calcareous benthic and planktonic foraminifera (Fig. 3).

In the upper part of this interval planktonic foraminifera are still abundant (dominated by $H$. globulosa and $G$. volutus). However, between 9110 feet $(2777 \mathrm{~m})$ and 9290 feet $(2832 \mathrm{~m})$ the calcareous benthic and planktonic foraminifera are less abundant and the interval is characterized by Rhabdammina spp., Rhizammina spp., Saccammina spp., Psammosphaera spp., $R$. varians and C. ovula. 
At 9290 feet $(2832 \mathrm{~m})$ there is a downhole change in assemblage composition to dominantly calcareous foraminifera again, with abundant $H$. globulosa, G. volutus and Archaeoglobigerina spp.

In the lower part of the interval (9680-10200 feet, 2950 $3109 \mathrm{~m}$ ) calcareous foraminifera are less abundant again. Besides the common Rhabdammina spp., Rhizammina spp., Saccammina spp., Psammosphaera spp. and Recurvoides spp., the assemblage is characterized by C. ovula, and the Karrerulinal Gerochammina spp. group. In the northern North Sea and west of the Shetland Islands, the break between calcareous species above and non-calcareous forms below, is correlated with the Lower/Upper Maastrichtian boundary (upper boundary of Zone FCN20a of King et al., 1989; Ritchie et al., 1996).

\section{Reussella szajnochae 2 assemblage}

Interval: $10280-10520$ feet $(3133-3206 \mathrm{~m})$

Age: late Campanian

The upper boundary of this interval is marked by the downhole shift to abundant calcareous foraminifera and the downhole reappearance of Reussella szajnochae. The planktonic foraminifera are dominated by $G$. volutus and Archaeoglobigerina spp. The LO event of $R$. szajnochae 2 is reported to mark the Campanian/ Maastrichtian boundary (top of Zone FCN19 of King et al., 1989; Ritchie et al., 1996).

\section{Agglutinated foraminifera dominated assemblage}

Interval: $10520-11210$ feet $(3206-3417 \mathrm{~m})$

Age: mid-Campanian

The top of this interval is characterized by a downhole change to a dominantly agglutinating fauna. In this interval the recovered assemblage consists only of long-ranging taxa, with common Rhabdammina spp., Rhizammina spp., Saccammina spp., Psammosphaera spp., Recurvoides spp. and C. ovula. In the lowest part of the interval pyritized moulds of radiolarians and diatoms become more abundant. The influx of a characteristic conical shaped diatom infilling (Fenestrella sp. 1) marks the lower boundary of this interval.

\section{Fenestrella sp. 1 assemblage \\ Interval: $11210-11720$ feet $(3417-3572 \mathrm{~m})$ \\ Age: early Campanian}

The influx of pyritised moulds of Fenestrella sp. 1 characterizes this interval, which is accompanied by very abundant pyritized infillings of other diatom species and radiolarians (pyritized and non-pyritized). The lower boundary of this interval (Santonian/Campanian boundary) is indicated by the LCO of characteristic shell fragments of Inoceramus spp. An alternative marker for this event is the influx of large, nonpyritized, spherical radiolarians. The occurrence of Fenestrella sp. 1 is also recognized in the Haltenbanken area of the Norwegian margin (Gradstein, personal observations). King et al. (1989) and Ritchie et al. (1996) did not separate the last two assemblages: the Fenestrella sp. 1 assemblage was incorporated in their Lower Campanian interval of dominantly non-calcareous foraminifera (FCN18).

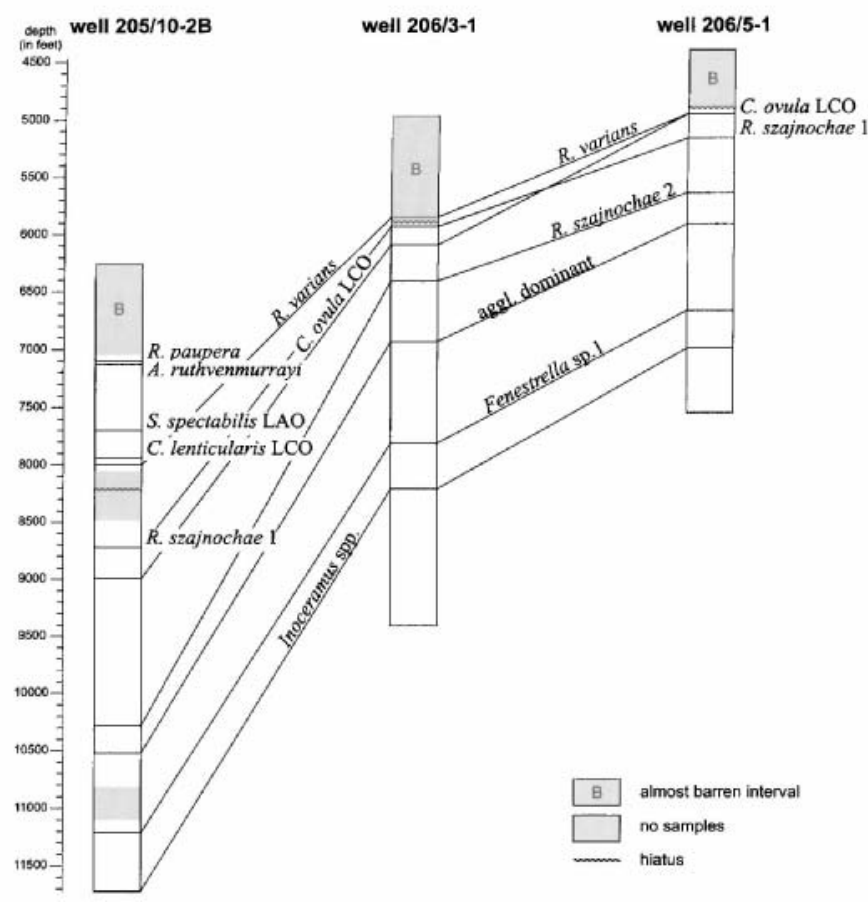

Fig. 4. Biostratigraphic correlation of last occurrences and last common occurrences (LCO) of nominate taxa in three studied wells in the Foula Sub-basin.

10. Inoceramus spp. assemblage

Sample: 11720 feet $(3572 \mathrm{~m})$

Age: Santonian

Little information is available for this Santonian assemblage, as only the lowermost studied sample contains common inoceramid prisms. The biosiliceous microfossils (diatoms and radiolarians) are still very abundant in this sample.

\section{Biostratigraphic correlation}

To test the regional applicability of the biostratigraphic events described from well $205 / 10-2 \mathrm{~B}$, a correlation between the last occurrence events of the nominate taxa observed in the three studied wells is shown in Fig. 4. Only last occurrence (LO) and last common occurrence (LCO) events are considered here, because we are dealing with ditch cutting samples in this study. In the situations where events occur close to the erosional upper boundary of the Shetland Group, the true extinction level of these taxa might have been eroded during the early Palaeocene erosional event. Consequently, the observed last occurrence of a taxon might not be correlative to its true stratigraphic extinction level. Unfortunately, the Palaeocene samples of wells 206/3-1 and 206/5-1 are almost barren of microfossils; therefore, in the discussion we concentrate on the Campanian-Maastrichtian events of the Shetland Group.

All events described from well 205/10-2B are recognized in the other wells. In all three wells the LO of $R$. varians was observed close to the erosional upper boundary of the Shetland Group, which suggests that the true LO level of this species might have been eroded during the basal Palaeocene erosional event. The same holds true for the LCO event of C. ovula in well 206/5-1. 


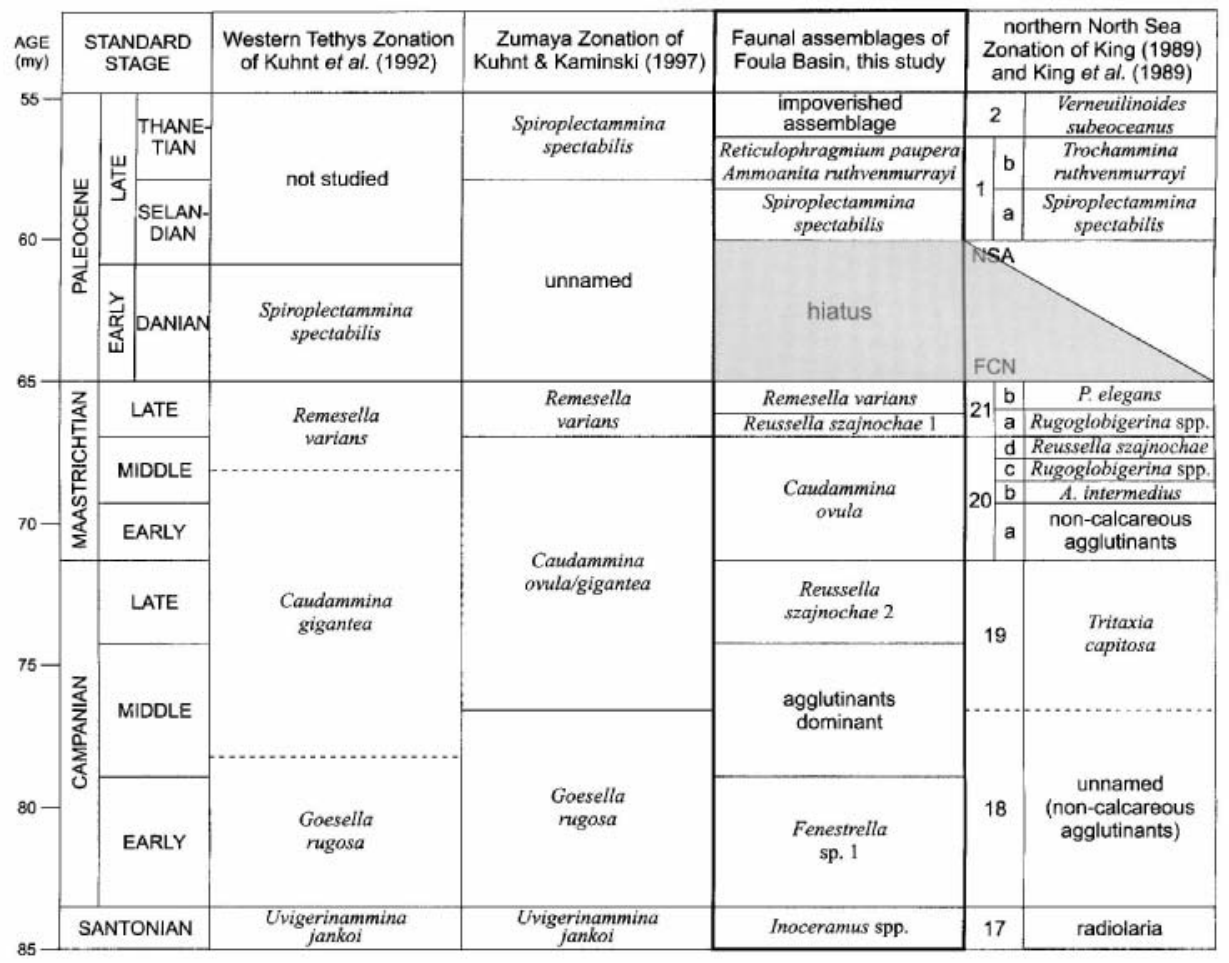

Fig. 5. A comparison between the assemblages from the Foula Sub-basin (well 205/10-2B), with the succession of Zones observed in the Western Tethys, Zumaya (Spain) and the northern North Sea (King, 1989; King et al., 1989; Kuhnt et al., 1992; Kuhnt \& Kaminski, 1997).

Both species are known to range into the Upper Palaeocene in other areas (Kaminski et al., 1988), so their LOs observed here are local events.

One striking feature of the correlation of the wells is the order of events of $C$. ovula and $R$. szajnochae 1 in well 206/5-1 with respect to the order described from wells 205/10-2B and 206/3-1 (Fig. 4). The true stratigraphic order of the LO events of $C$. ovula and $R$, szajnochae 1 remains an unsolved problem. Studies of more wells in the basin might give an indication of the stratigraphic utility of the LCO event of $C$. ovula and its position with respect to the LO of $R$. szajnochae 1 .

Although the occurrence of planktonic and calcareous benthic foraminifera is affected by post-mortem preservation, there is a possibility that the three distinct Campanian and Maastrichtian calcareous foraminiferal influxes recognized in well 205/10-2B (Fig. 3) may serve as extra correlation markers. So far, these three events are only recognized in wells $205 / 10-2 \mathrm{~B}$ and $206 / 5-1$. A detailed study of assemblages in well 206/3-1 should reveal its correlative applicability for the Foula Sub-basin.

The stratigraphical succession of cosmopolitan species on the Northeast Atlantic margin displays many features in common between the studied sections, although there are notable local differences. In Fig. 5 the assemblages of four study areas are arranged from South to North for comparison. The study of the Foula Sub-basin provides an important link between the southern and northern regions of the North Atlantic. For the description of the assemblages in this study, and the zonation of King (1989) and King et al. (1989), only last occurrences of the index species are considered, whereas for the definition of zones in the Western Tethys, both last and first occurrences are used
(Kuhnt et al., 1992; Kuhnt \& Kaminski, 1997).

In the Western Tethys, the lower to middle Campanian is characterized by abundant Goesella rugosa (Hanzlíková, 1955). Only a few specimens of $G$. rugosa have been recovered from the Foula Sub-basin and the North Sea; therefore, other criteria are used for correlation in the northern Northeast Atlantic margins for this interval. In the Foula Sub-basin and northern North Sea Caudammina gigantea is very rare or absent, although $C$. ovula, the smaller, closely related form of $C$. gigantea, is commonly observed. The consistent occurrence of Remesella varians in all four studied areas makes it a reliable index species, although its occurrence might be limited in places by calcite dissolution (it is a calcite cemented agglutinated taxon). During the Palaeocene, Spiroplectammina spectabilis occurs throughout the whole Northeast Atlantic margin. However, during the late Palaeocene high abundances are only observed in the Foula Sub-basin and northern North Sea region. The additional observation of high abundances in the western Barents Sea implies that high abundances of this taxon may be confined to the late Palaeocene Boreal area (Nagy et al., 1997).

The differences in abundances of certain index taxa suggest there are some noticeable palaeobiogeographical differences between Tethyan-related and more Boreal assemblages: $G$. rugosa and $C$. gigantea can be regarded as predominantly Tethyan species, whereas the high abundances of S. spectabilis during the late Palaeocene are typical of Boreal regions.

\section{Basal Palaeocene unconformity}

The lithostratigraphy and biostratigraphy provide constraints about the timing and extent of the early Palaeocene erosional 
event in the Foula Sub-basin. The main cause for this event is the Icelandic mantle plume, which induced major thermal uplift in the Faeroe-Shetland Basin, causing regional extension. The extension was accompanied by uplift and erosion on the West Shetland margin with, simultaneously, deposition of the erosional products as submarine fans in the accelerated subsiding basin (Earle et al., 1989). The uplift of the West Shetland Platform and Basin during the late early Palaeocene led to erosion in large areas of the Foula Sub-basin, resulting in the basal Palacocene unconformity. Further to the NW, deep marine sedimentation still took place, which is deduced from seismic and well data in the Faeroe-Shetland Basin, indicating that the Palaeocene succession increases rapidly in thickness NW of the Flett Ridge (Mudge \& Rashid, 1987). From early late Palaeocene times onward, marine sedimentation continued across almost the entire Faeroe-Shetland Basin. The Rona Ridge acted as the shelf edge from where submarine fans prograded into deeper parts of the basin (Knott et al., 1993). Occasionally, erosional events took place on the Rona Ridge and in the West Shetland Basin. By the end of late Palaeocene times, marginal marine to shallow marine conditions prevailed into the early Eocene.

The lithostratigraphy and biostratigraphy of the three studied wells in the Foula Sub-basin fit adequately within this history of erosion and deposition. The area of the Flett Ridge (well 205/102B) is furthest away from the uplifted Shetland Platform and is only affected by the early Palaeocene erosional event. The hiatus encompasses Upper Maastrichtian to Lower Palaeocene sediments, as upper Lower Palaeocene sediments of the Sullom Formation rest unconformably on upper Maastrichtian sediments. Deposition of deep marine mudstones of the Upper Palaeocene Vaila and Lamba Formations continued after this event, while the central part of the Foula Sub-basin (well 206/31) and its SE margin (well 206/5-1) were subjected to continuing crosional events. During the late Palaeocene, deposition took place in a shallow marine environment with deposition of progradational and aggradational wedges of coastal plain facies of the Flett Formation into a relatively shallow sea (Knox et al., 1997).

The lower limit of the Palaeocene erosional events is indicated by the index species observed in the Maastrichtian mudstones. In well 206/3-1 part of the latest Maastrichtian is still present, as is indicated by the abundance of Pseudotextularia elegans (nominate taxon of latest Maastrichtian Zone FCN21b of King et al., 1989; Ritchie et al., 1996). In the other two studied wells this species is absent in the highest Cretaceous samples analysed, indicating a late Maastrichtian age (Zone FCN21a of King et al., 1989).

To conclude, a major erosional event in the Foula Sub-basin took place during the early Palaeocene. In well 205/10-2B the hiatus encompasses the late Maastrichtian to earliest Palaeocene; in well 206/3-1 uppermost Maastrichtian to lower upper Palaeocene sediments are eroded, and in well 206/5-1 upper Maastrichtian to Lower Palaeocene sediments are absent.

\section{Palaeoenvironment}

The microfaunal assemblages in the studied wells can be subdivided into calcareous and dominantly non-calcareous intervals. There are two scenatios which can explain this observed pattern.

The first is that intervals with a diversified dominant agglutinated fauna could indicate phases of more restricted circulation in a deep water basin (Gradstein \& Berggren, 1981). With restricted water circulation, the oxygen level at the sea floor drops and simultaneously the carbon dioxide level increases. This produces an acid reducing environment where calcium carbonate will easily dissolve; hence, calcareous benthic and planktonic foraminifera will be rare or absent in the sediment due to post-mortem dissolution. In contrast, intervals with abundant calcareous benthic and planktonic foraminifera are interpreted as reflecting periods with normal open marine circulation. Restricted water circulation can be induced in a semi-enclosed basin in relation to a low sea-level. The surface water circulation will be normal, while the deeper water column will be more stagnant. The influx of planktonic foraminifera will not be preserved in the sediment due to calcium carbonate dissolution. During periods of high sea level, deeper circulation of the basin is possible and the calcareous fauna will be preserved in the sediment.

As a second scenario, dysaerobic conditions at the seafloor can also be induced by high surface water productivity, most likely in relation to coastal upwelling. Decomposition of organic matter in the water column leads to oxygen deficiency and dissolution of calcium carbonate. In this case, intervals with a dominant agglutinated fauna would reflect periods of enhanced upwelling. However, the agglutinated foraminiferal fauna does not infer dysaerobic bottom water conditions during the noncalcareous intervals. Infaunal taxa are reported to be abundant in dysaerobic environments (Kaminski et al., 1995), but in well 205/10-2B these taxa display low abundances throughout the studied section. Therefore, we can conclude that the bottom waters were well oxygenated or only slightly dysaerobic during the agglutinated foraminifera dominated intervals.

Whether the observations of planktonic foraminifera are related to post-mortem dissolution in a semi-enclosed basin or during periods of enhanced upwelling, they indicate influxes of North Atlantic surface water masses flowing northwards through the basin. Palaeogeographical patterns displayed by agglutinated foraminiferal fauna implies the same North Atlantic circulation: there is a close taxonomic affinity between the assemblages in the Foula Sub-basin and the assemblages from Trinidad (Kaminski et al., 1988). For example, Ammobaculites cf. jarvisi (Cushman and Renz, 1946), Goesella rugosa and Rzehakina epigona var. lata (Cushman and Jarvis, 1928) are common in Trinidad and Venezuela, but very rare or unreported in the North Sea region.

In addition to foraminifera, diatom infillings and radiolarians are also present in the studied sections. They are especially abundant in the Lower Campanian. This biosiliceous event is known as the 'Lower to Middle Campanian Event' and is recognized worldwide (Moullade et al., 1988; Thurow, 1988; Kuhnt et al., 1989, 1992; Kuhnt, 1990). The enhanced biosiliceous surface water productivity reflects major oceanic events (upwelling, change in the Carbonate Compensation Depth, change in oceanic circulation or an increase in volcanic activity), which are mainly related to the formation of the Atlantic Basin, but not yet completely understood (Thurow, 1988). 


\begin{tabular}{|c|c|c|c|c|c|}
\hline MORPHOTYPE & TEST SHAPE & $\begin{array}{l}\text { MORPHO- } \\
\text { GROUP }\end{array}$ & LIFE POSITION & FEEDING HABIT & ENVIRONMENT \\
\hline & tubular & M1 & erect epifauna & $\begin{array}{l}\text { suspension } \\
\text { feeding }\end{array}$ & $\begin{array}{l}\text { tranquil bathyal and } \\
\text { abyssal with low } \\
\text { organic matter flux }\end{array}$ \\
\hline & globular & M 2 a & shallow infauna & $\begin{array}{c}\text { suspension feeding } \\
\text { - } \\
\text { passive } \\
\text { deposit feeding }\end{array}$ & bathyal and abyssal \\
\hline & $\begin{array}{c}\text { rounded } \\
\text { trochospiral } \\
\text { and } \\
\text { streptospiral }\end{array}$ & M 2 b & surficial epifauna & $\begin{array}{c}\text { active } \\
\text { deposit feeding }\end{array}$ & $\begin{array}{l}\text { shelf to } \\
\text { marginal marine }\end{array}$ \\
\hline & $\begin{array}{l}\text { elongate } \\
\text { keeled }\end{array}$ & M $2 c$ & surficia! epifauna & $\begin{array}{c}\text { active } \\
\text { deposit feeding }\end{array}$ & $\begin{array}{l}\text { shelf to } \\
\text { marginal marine }\end{array}$ \\
\hline & $\begin{array}{c}\text { flattened } \\
\text { trochospiral } \\
\text { flattened } \\
\text { planispiral } \\
\text { and } \\
\text { streptospiral }\end{array}$ & M 3 a & surficial epifauna & $\begin{array}{c}\text { active } \\
\text { and } \\
\text { passive } \\
\text { deposit teeding }\end{array}$ & $\begin{array}{l}\text { high energy } \\
\text { lagoon and estuary }\end{array}$ \\
\hline & $\begin{array}{l}\text { flattened } \\
\text { jrregular }\end{array}$ & $M 3 b$ & surficial epifauna & $\begin{array}{c}\text { passive } \\
\text { deposit feeding }\end{array}$ & $\begin{array}{l}\text { upper bathyal } \\
\text { to abyssal }\end{array}$ \\
\hline & $\begin{array}{l}\text { rounded } \\
\text { planispiral }\end{array}$ & M 4 a & $\begin{array}{c}\text { surficial epifauna } \\
\text { shallow infauna }\end{array}$ & $\begin{array}{c}\text { active } \\
\text { deposit feeding }\end{array}$ & $\begin{array}{l}\text { inner shelf } \\
\text { to upper bathyal }\end{array}$ \\
\hline 而 & $\begin{array}{c}\text { elongate } \\
\text { subcylindrical }\end{array}$ & M 4 b & deep infauna & $\begin{array}{c}\text { active } \\
\text { deposit feeding }\end{array}$ & $\begin{array}{l}\text { inner shelf to upper } \\
\text { bathyal with } \\
\text { increased organic } \\
\text { matter flux }\end{array}$ \\
\hline
\end{tabular}

Fig. 6. Morphogroup definition of agglutinated foraminifera (modified after Nagy et al., 1995 and 1997).

\section{Palaeobathymetry and palaeoecology}

Using modern faunas as an analogue, relative proportions of the morphogroups, present in an assemblage, may be used to interpret changes in environmental parameters, such as water depth, current strength and organic flux to the sea floor. Morphogroups are defined on basis of the external morphology of the foraminiferal test. Agglutinated foraminiferal test shapes are thought to reflect differences in life position and feeding habit (Jones \& Charnock, 1985; Nagy, 1992; Nagy et al., 1995). The morphogroup classification of agglutinating foraminifera used here for the assemblages of well 205/10-2B, includes four main groups and eight morphotypes (based on work by Nagy et al., 1995 and 1997), and is summarized in Fig. 6.

Morphogroup 1 comprises all epifaunal tubular taxa (belonging to the genera Rhizammina, Rhabdammina, and Bathysiphon) with a suspension feeding habit. Their erect life position is adapted to environments with a low organic flux to the seafloor. In modern settings, they are abundant in tranquil lower bathyal to abyssal environments (Schröder, 1986).

Three morphotypes are identified in morphogroup 2, involving a deposit feeding epifauna that often lives at or just below the sediment surface, feeding on bacteria and detritus from the flocculent layer (Nagy, 1992). The first morphotype (2a) includes the unilocular globular taxa: Saccammina and Psammosphaera. The multilocular uniserial taxa, of which only single chambers are found in the samples, are included in this group (Caudammina and Aschemocella). Like the taxa of morphogroup 1, in modern oceans they are abundant at lower bathyal to abyssal water depths (Nagy et al., 1995). In the second morphotype (2b), two different forms have been arranged. The first form comprises the more rounded trochospiral and streptospiral taxa (Recurvoides and Thalmannammina). The other form includes the planoconvex trochospiral forms with a rounded periphery (Trochammina and Ammoanita). In modern environments, morphotype $2 \mathrm{~b}$ is most common in shelf and marginal marine waters (Nagy et al., 1995). The elongate keeled forms of the third morphotype (2c) (Spiroplectammina spectabilis and Spiroplectinella) are interpreted as having also an epifaunal life habit.

The two morphotypes of morphogroup 3 contain the flattened taxa, of which the flat test is not caused by post-mortem compaction. The flattened trochospiral (Lepidoparatrochammi- 


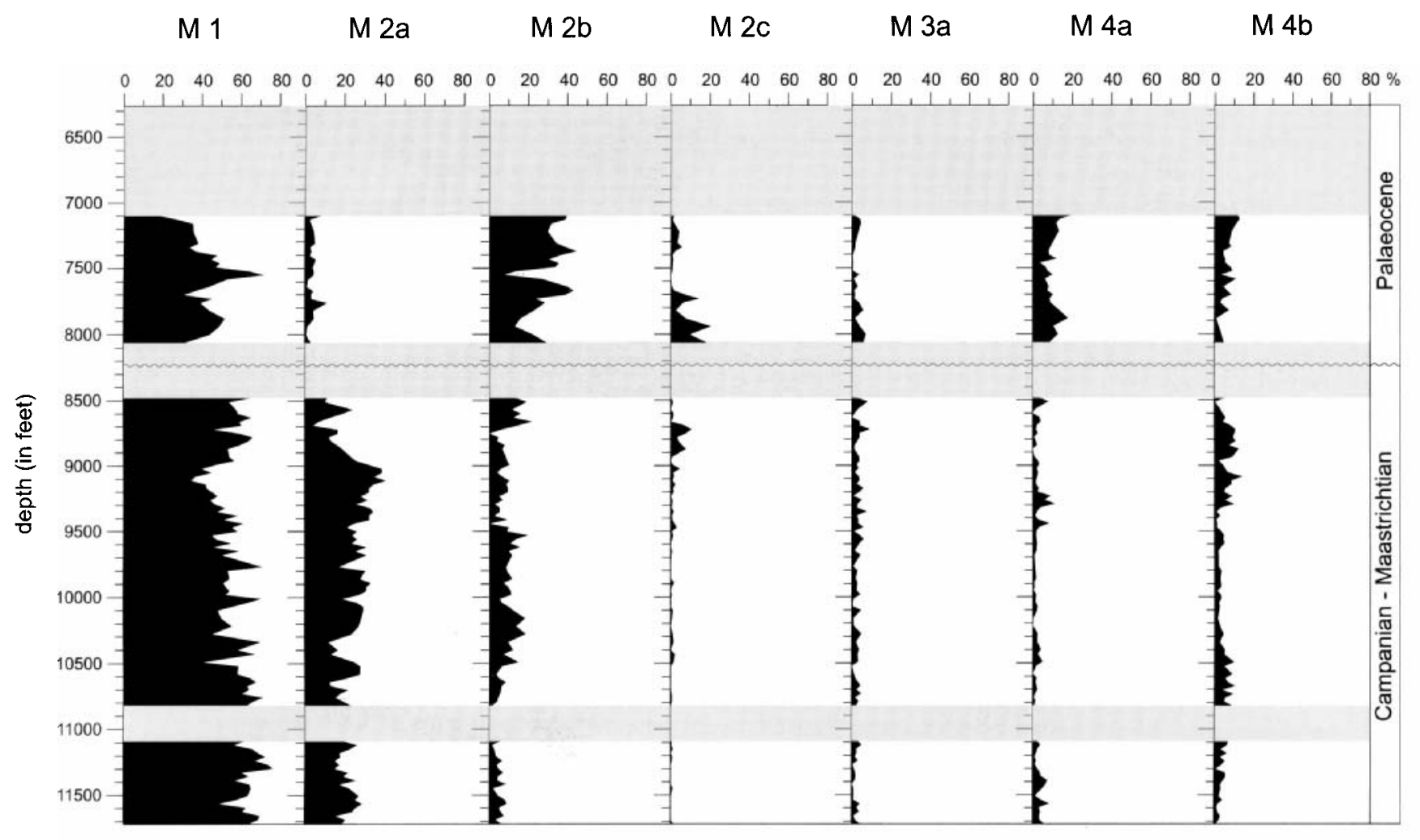

Fig. 7. Relative distribution (in percentage) of agglutinated foraminiferal morphogroups in well 205/10-2B. Grey shadings indicate almost barren intervals or interval where no samples were available ( $8060-8480 \mathrm{feet}, 2457-2585 \mathrm{~m})$.

na) and flattened planispiral and streptospiral forms (Ammodiscus, Glomospira and Rzehakina) are included in morphotype 3a. They live attached to elevated surfaces or seaweeds, or on the surface of the sediment (Nagy et al., 1995). In modern faunas, they are most abundant in high energetic marginal marine environments (marshes and lagoons) (Nagy et al., 1995). On the other hand, the single representative taxon of morphotype $3 \mathrm{~b}$ in this study (Ammolagena clavata) is reported to be a significant contributor to the assemblage in upper bathyal and deeper environments (Schröder, 1986; Nagy et al., 1995).

Morphogroup 4 comprises the infaunal forms and includes two different morphotypes. These forms are better adapted to life in areas of increased organic flux and higher nutrient supply (Nagy et al., 1997). The planispiral forms with a rounded periphery belong to morphotype 4a (Haplophragmoides, Reticulophragmium and Cribrostomoides). These forms live in the flocculent layer or in the sediment close to the sediment - water surface. However, these are minor contributors to the faunal assemblages from modern inner shelf to upper bathyal water depths (Nagy et al., 1995). Both the multilocular, elongate subcylindrical (Karrerulina, Remesella, and Gerochammina) and elongate, tapered forms (Reophax and Verneuilinoides) make up the contribution of morphotype $4 \mathrm{~b}$. Under normal conditions, these forms inhabit a deep infaunal habitat, where they scavenge the sediment for bacteria and detritus (Nagy, 1992; Nagy et al., 1995). In addition, this group is reported to be abundant in areas where the surface layer of the sediment is affected by bottom currents or in dysaerobic environments (Kaminski, 1985;
Kaminski et al., 1995). In general, they are most common in inner shelf to upper bathyal environments with moderate contributions to the faunal assemblages in lagoonal and marsh environments (Nagy et al., 1995).

The results of the morphogroup analysis of the agglutinated foraminifera in well 205/10-2B are shown in Figure 7 . The tubular taxa of morphogroup 1 are common throughout the studied section, with lower contributions in the Palaeocene interval. Frequency variations of this morphogroup are interpreted to reflect changes in the palaeobathymetric history of the studied site (Nagy et al., 1997). In the Campanian-Maastrichtian part of the section this morphogroup is the main contributor to the assemblage. However, in the interval 9000 9300 feet $(2743-2835 \mathrm{~m})$ their relative proportion is somewhat lower, which suggests a shallowing of water depth in the area. On the other hand, the relative proportions of morphotype $2 \mathrm{a}$ are increased in the same interval. Together with the taxa of morphogroup 1, the taxa of morphotype $2 \mathrm{a}$ are most abundant in lower bathyal and abyssal environments in modern oceans (Nagy et al., 1995). Based on the relative proportions of these two morphotypes, they indicate contradictory bathymetric trends. There is no other evidence which suggests a shallower water depth during this interval. Calculation of the total number of specimens of taxa representing a morphogroup per studied gram of a sample reveals that there is a small increase in the number of morphotype 2a per gram in the interval $8900-9300$ feet $(2713-2835 \mathrm{~m})$, while the numbers of morphogroup 1 per gram stay constant in the same interval. So the trend observed in 
the relative proportions of morphogroup 1 is related to the closed sum effect due to a small increase in the absolute abundance of morphotype $2 \mathrm{a}$. In conclusion, a lower bathyal depositional environment is inferred for the whole Campanian and Maastrichtian interval.

The difference in the relative proportion of the morphogroups between the intervals above and below the unconformity is most obvious from morphotype $2 \mathrm{a}$ : in the Palaeocene part (7100-8060 feet, $2164-2457 \mathrm{~m}$ ) this group is almost absent (Fig. 7). In the same interval of the studied section morphogroup 1 is still common, but is present in lower proportion as in the Cretaceous interval. Higher abundances in the Palaeocene interval of the epifauna and shallow infauna (morphotypes $2 \mathrm{~b}$ and $4 \mathrm{a}$ respectively) indicate a shallower depositional environment in a middle to upper bathyal water depth (Nagy et al., 1995).

\section{SUMMARY}

Among the three studied wells located in the Foula Sub-basin on the western margin of the Shetland Islands, well $205 / 10-2 B$ is chosen as a stratigraphic reference section for the CampanianPalaeocene interval. A total of 153 agglutinating species and taxa in open nomenclature taxa are recognized. Based on the succession of shelly microfossils (benthic and planktonic foraminifera, diatoms and radiolarians) the section can be subdivided into ten stratigraphically distinct assemblages. For correlation and palaeoceanographic purposes, this study area provides an important link between the northern and southern areas of the northeast Atlantic margin.

The composition of the foraminiferal assemblages indicates that deposition took place in a well oxygenated, deep marine environment with influxes of North Atlantic surface water masses. Analysis of agglutinated benthic foraminiferal morphogroups in the reference section indicates a shallowing of the basin over the widespread lower Palaeocene unconformity.

\section{ACKNOWLEDGEMENTS}

We gratefully acknowledge a research grant from Saga Petroleum, Norway, which enabled us to carry out this study. We thank R. W. Gatliff (BGS Edinburgh) for providing well data. Samples were kindly provided by the Department of Trade and Industry Core Facility, Edinburgh. We thank Vijay Thusu for all her help. We wish to thank $H$. Bailey and an anonymous reviewer for comments on the final manuscript. This is contribution no.63 of the Deep-water Agglutinated Foraminifera Project.

\section{REFERENCES}

Berggren, W. A. \& Norris, R. D. 1997. Biostratigraphy, phylogeny and systematics of Paleocene trochospiral foraminifera. Micropaleontology, 43(supplement 1): 1-116.

Caron, M. 1985. Cretaceous planktic foraminifera. In Bolli, H. M. , Saunders, J. B. \& Perch-Nielsen, K. (Eds), Plankton Stratigraphy Volume 1: Planktic Foraminifera, Calcareous Nannofossils and Calpionellids, Cambridge University Press, Cambridge: 17-86.

Chalmers, J. A., Larsen, L. M. \& Pedersen, A. K. 1995. Widespread Palaeocene volcanism around the northern North Atlantic and Labrador Sea: evidence for a large, hot, early plume head. Journal of the Geological Society, London, 152: 965-969.

Duindam, P. \& van Hoorn, B. 1987. Structural evolution of the West Shetland continental margin. In Brooks, J. \& Glennie, K. W. (Eds),
Petroleum Geology of North West Europe: Proceedings of the 3rd Conference. Graham \& Trotman, London, 765-773.

Earle, M. M., Jankowski, E. J. \& Vann, I. R. 1989. Structural and Stratigraphic Evolution of the Faeroe-Shetland Channel and Northern Rockall Trough. In Tankard, A. J. \& Balkwill, H. R. (Eds), Extensional tectonics and stratigraphy of the North Atlantic margins. AAPG Memoir 46: 461-469.

Ebdon, C. C., Granger, P. J., Johnson, H. D. \& Evans, A. M. 1995. Early Tertiary evolution and sequence stratigraphy of the FaeroeShetland Basin: Implications for hydrocarbon prospectivity. In Scrutton, R. A. , Stoker, M. S., Shimmield, G. B. \& Tudhope, A. W. (Eds), The Tectonics, Sedimentation and Palaeoceanography of the North Atlantic Region. Geological Society, London, Special Publications 90: 51-69.

Gradstein, F. M. \& Bäckström, S. A. 1996. Cainozoic biostratigraphy and palaeobathymetry, northern North Sea and Haltenbanken. Norsk Geologisk Tidsskrift, 76: 3-32.

Gradstein, F. M. \& Berggren, W. A. 1981. Flysch-type agglutinated foraminifera and the Maestrichtian to Paleogene history of the Labrador and North Seas. Marine Micropaleontology, 6: 211-268.

Gradstein, F. M., Kaminski, M. A. \& Berggren, W. A. 1988. Cenozoic foraminiferal biostratigraphy of the Central North Sea. In Gradstein, F. M. \& Rögl, F. (Eds), Proceedings of the 2nd International Workshop on Agglutinated Foraminifera. Abhandlungen der Geologischen Bundesanstalt, 41: Wien: 97-108.

Gradstein, F. M., Kaminski, M. A., Berggren, W. A., Kristiansen, I. L. \& D'Iorio, M. A. 1994. Cenozoic biostratigraphy of the North Sea and Labrador Shelf. Micropaleontology, 40(supplement 1): 1-152.

Hitchen, K. \& Ritchie, J. D. 1987. Geological review of the West Shetland area. In Brooks, J. \& Glennie, K. W. (Eds), Petroleum Geology of North West Europe; Proceedings of the 3rd Conference, Graham \& Trotman, London: 737-749.

Jones, G. D. 1988. A paleoecological model of Late Paleocene "Flyschtype" agglutinated foraminifera using the paleoslope transect appraoch, Viking Graben, North Sea. In Gradstein, F. M. \& Rögl, F. (Eds), Proceedings of the 2nd International Workshop on Agglutinated Foraminifera. Abhandlungen der Geologischen Bundesanstalt, 41: Wien: 143-153.

Jones, R. W. \& Charnock, M. A. 1985. 'Morphogroups' of agglutinated foraminifera. Their life positions and feeding habitats and potential applicability in (paleo-)ecological studies. Revue de Paléobiologie, 4(2): 311-320.

Kaminski, M. A. 1985. Evidence for control of abyssal agglutinated foraminiferal community structure by substrate disturbance: results from the Hebble area. Marine Geology, 66: 113-131.

Kaminski, M. A., Boersma, A., Tyszka, J. \& Holbourn, A. E. L. 1995. Response of deep-water agglutinated foraminifera to dysoxic conditions in the Californian basins. In Kaminski, M. A., Geroch, S. \& Gasinski, M. A. (Eds), Proceedings of the Fourth International Workshop of Agglutinated Foraminifera. Grzybowski Foundation. Special Publication no. 3: 131-140.

Kaminski, M. A., Gradstein, F. M., Berggren, W. A., Geroch, S. \& Beckmann, J. P. 1988. Flysch-type agglutinated foraminiferal assemblages from Trinidad: Taxonomy, Statigraphy and Paleobathymetry. In Gradstein, F. M. \& Rögl, F. (Eds), Proceedings of the 2nd International Workshop on Agglutinated Foraminifera. Abhandlungen der Geologischen Bundesanstalt, 41: Wien: 155-227.

King, C. 1989. Cenozoic of the North Sea. In Jenkins, D. G. \& Murray, J. W. (Eds), Stratigraphical Atlas of Fossil Foraminifera, (second edition). Ellis Horwood, Chichester: 418-489.

King, C., Bailey, H. W., Burton, C. A. \& King, A. D. 1989. Cretaceous of the North Sea. In Jenkins, D. G. \& Murray, J. W. (Eds), Stratigraphical Atlas of Fossil Foraminifera, (second edition). Ellis Horwood, Chichester: $372-417$.

Knott, S. D., Burchell, M. T., Jolley, E. J. \& Fraser, J. 1993. Mesozoic to Cenozoic plate reconstructions of the North Atlantic and hydrocarbon plays of the Atlantic margins. In Parker, J. R. (Ed.), Petroleum Geology of North West Europe: Proceedings of the 4th Conference. Geological Society, London; 953-974.

Knox, R. W. O. B., Holloway, S., Kirby, G. A. \& Bailey, H. E. 1997. Stratigraphic Nomenclature of the UK North West Margin : 2. Early Paleogene Lithostratigraphy and Sequence Stratigraphy. British 
Appendix: Microfossil distribution in samples from well 205/10-2B. Depths are in feet.

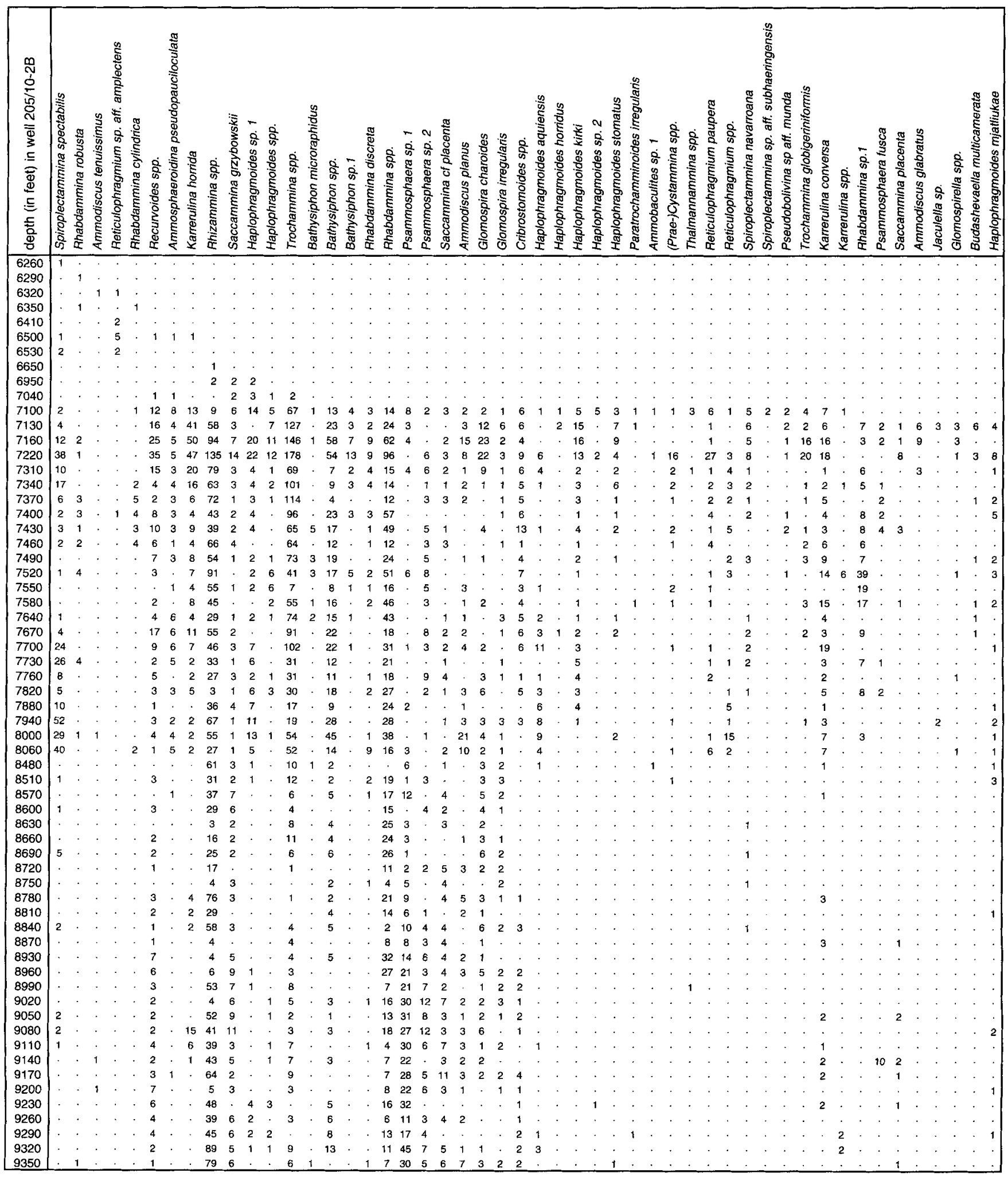




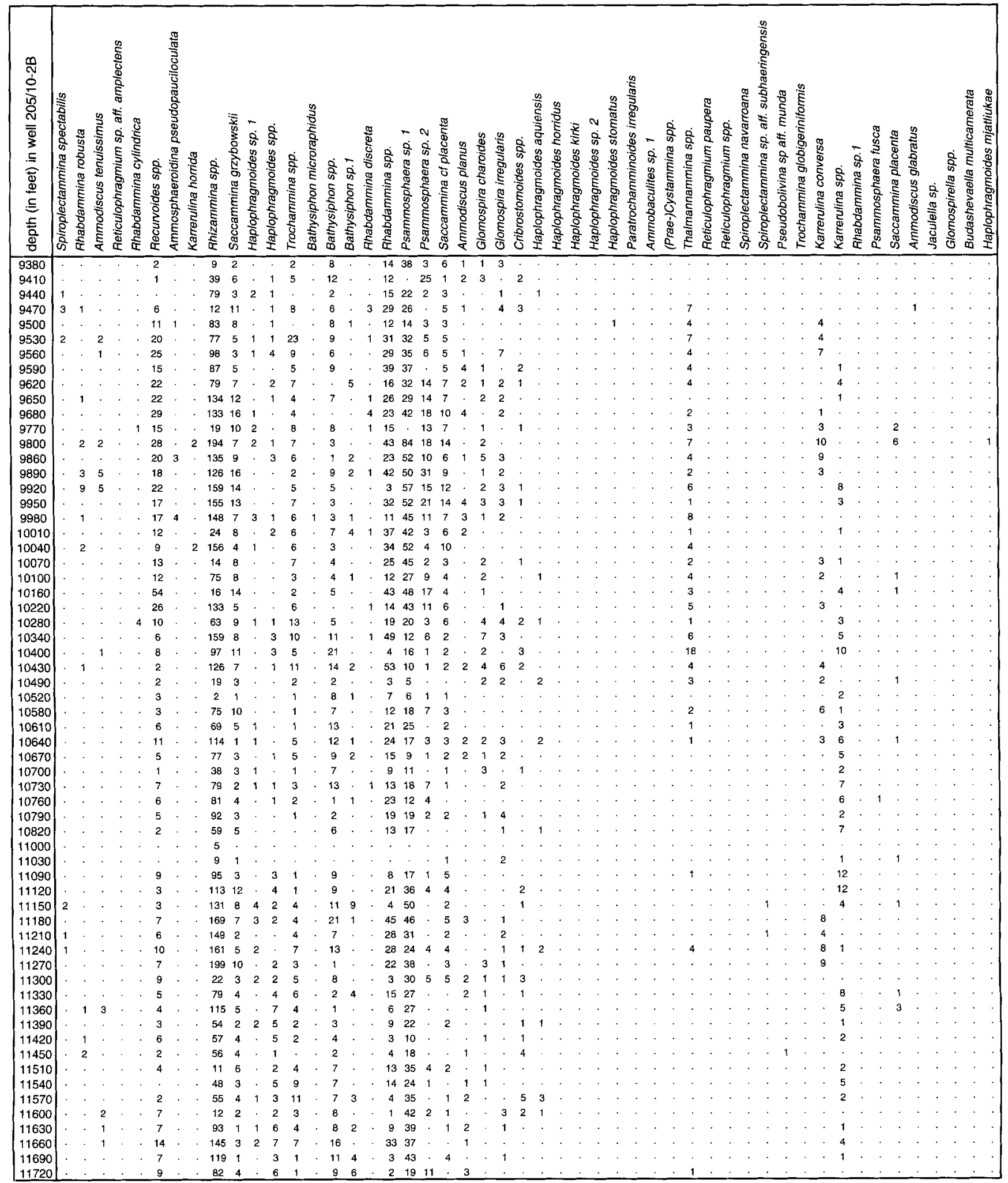




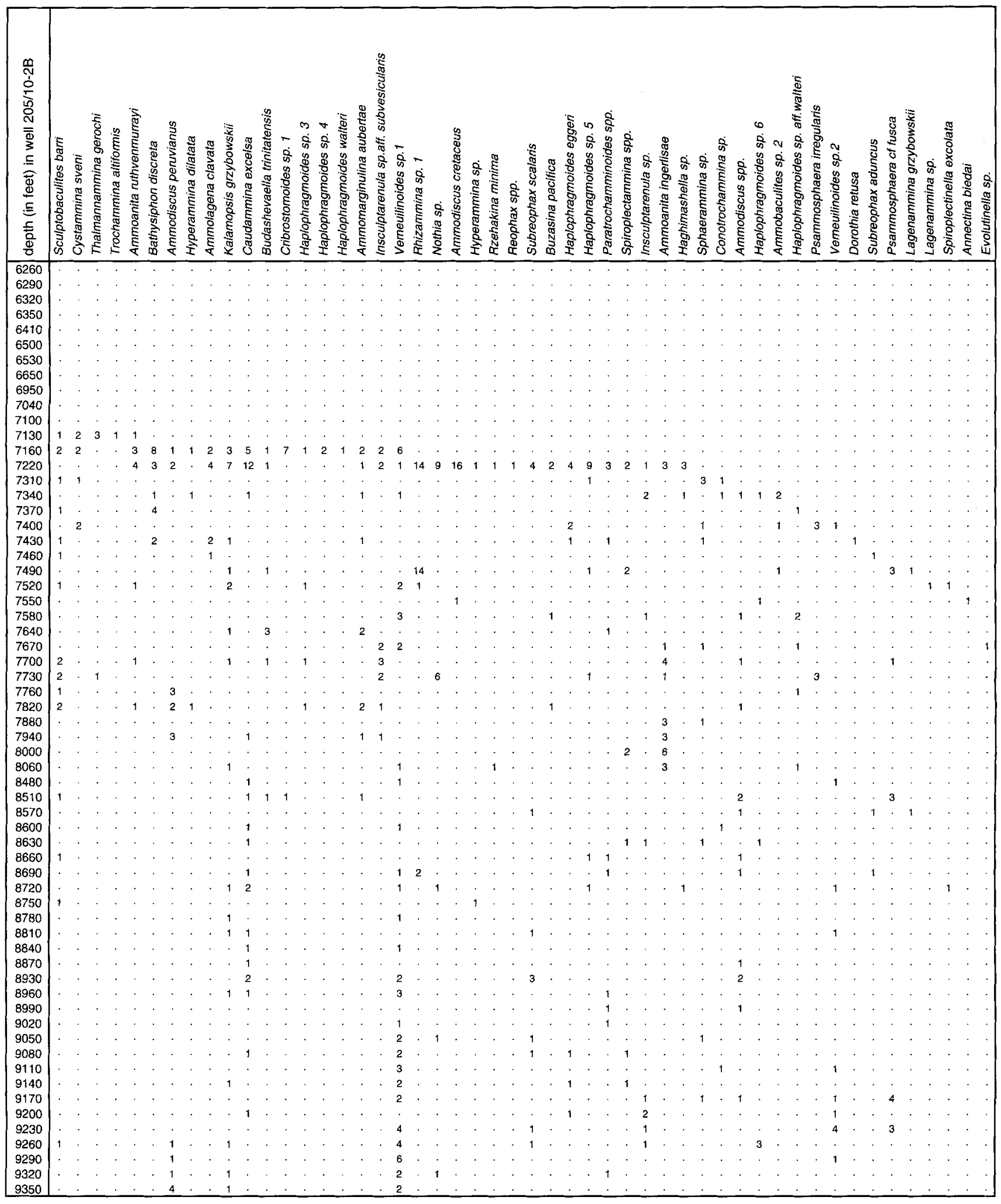




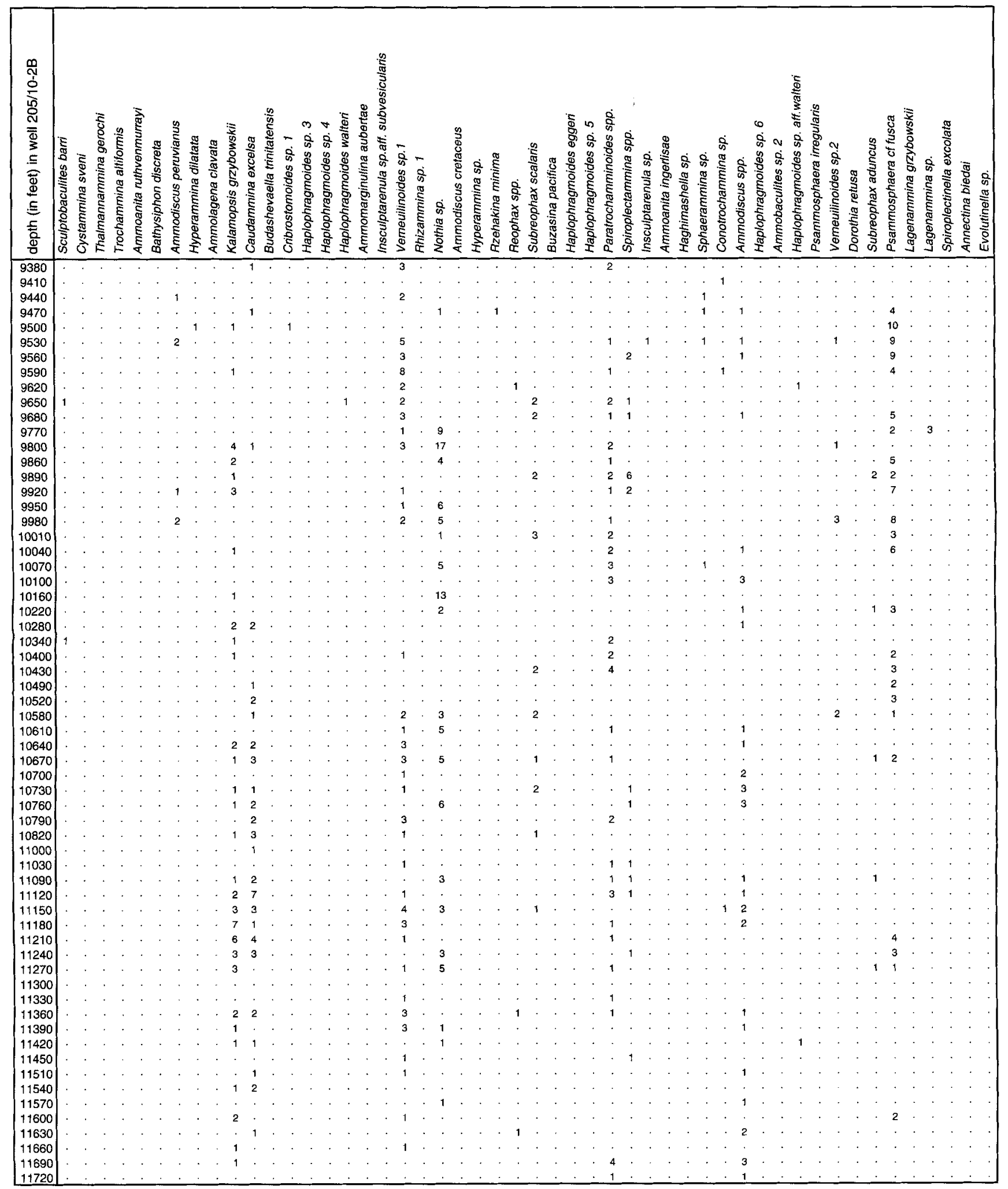


Appendix (continued) Microfossil distribution in samples from well 205/10-2B.

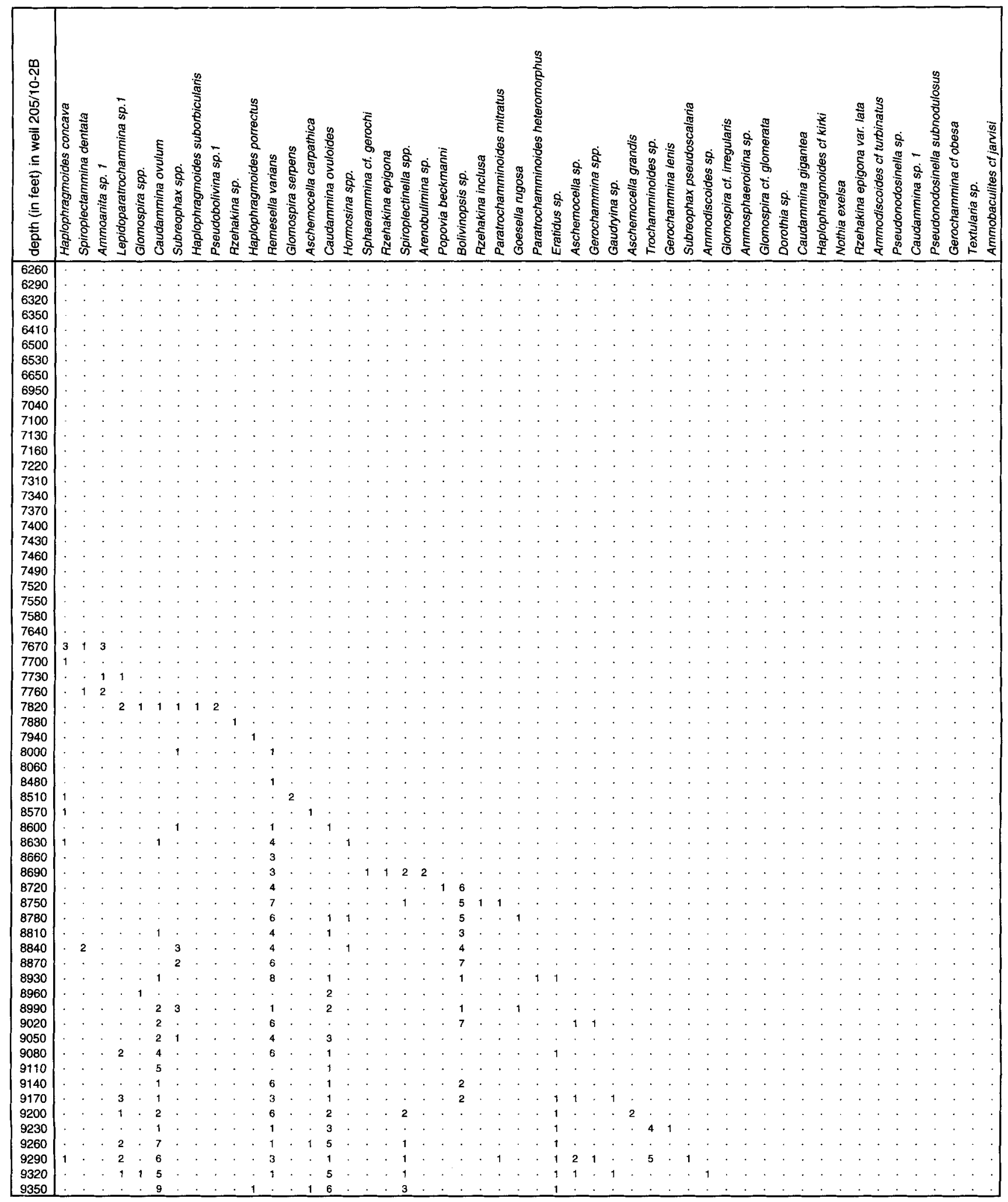




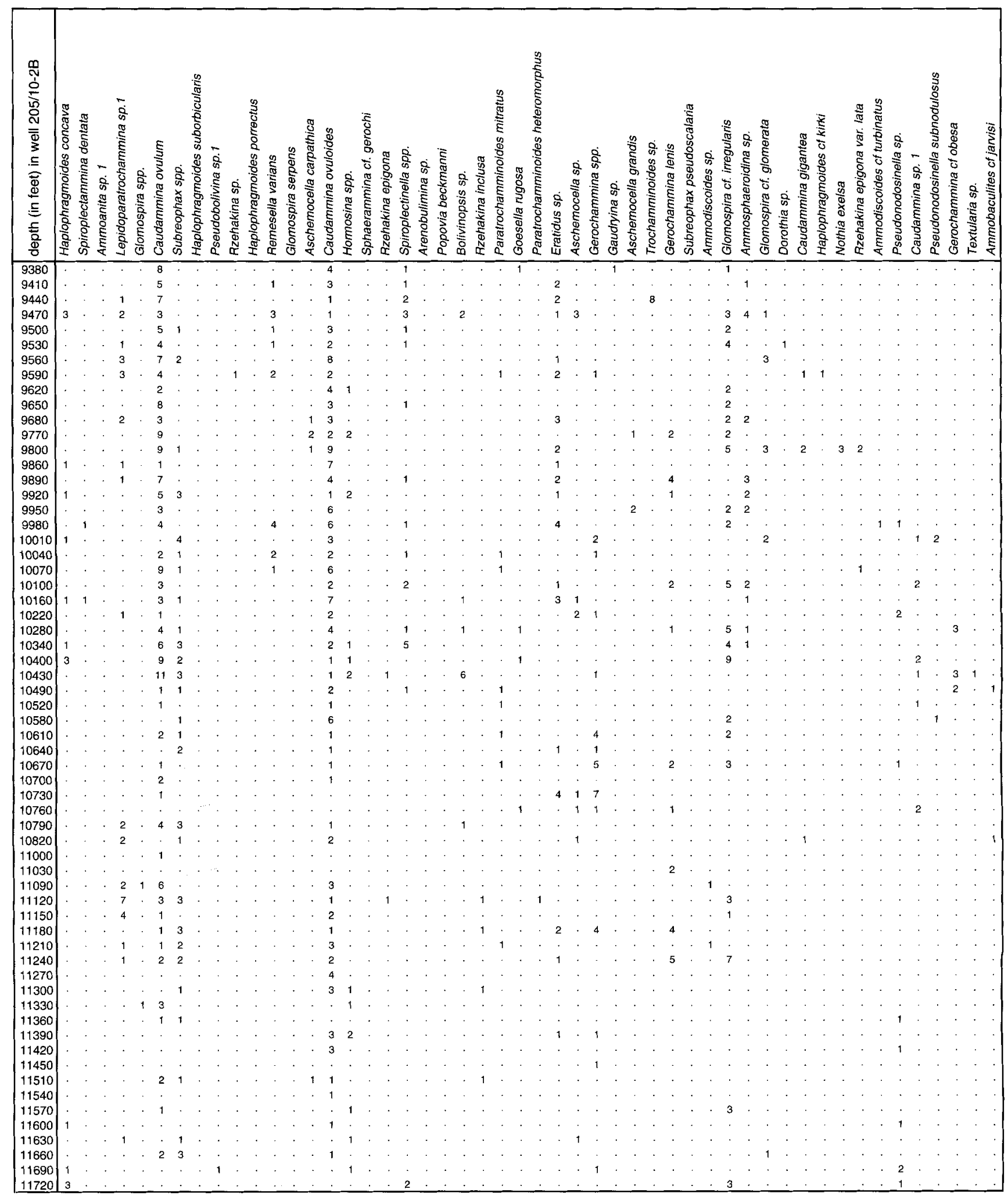


Appendix (continued) Microfossil distribution in samples from well 205/10-2B.

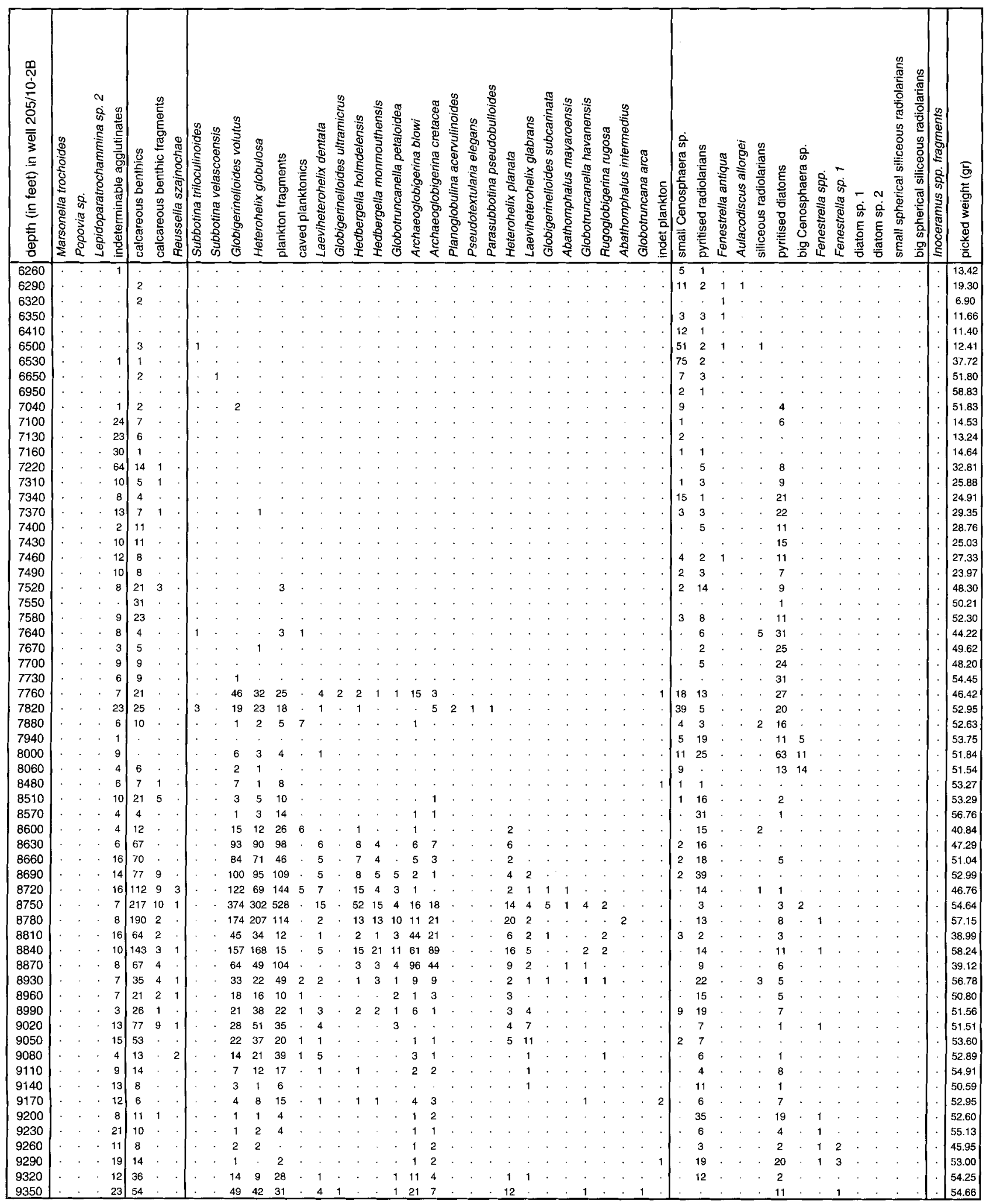


Appendix (continued) Microfossil distribution in samples from well 205/10-2B.

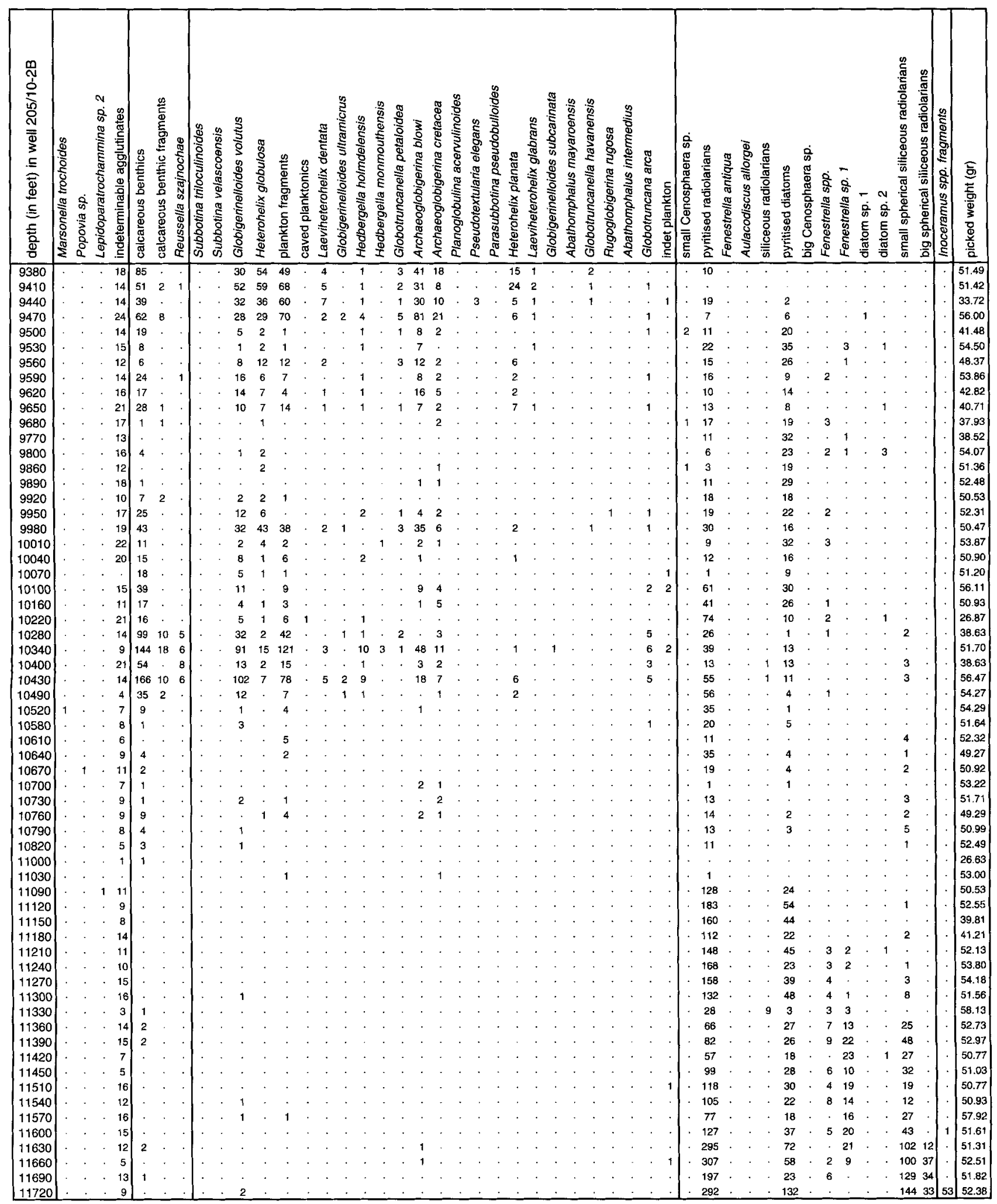


Geological Survey, Nottingham.

Kuhnt, W. 1990. Agglutinated foraminifera of western Mediterranean Upper Cretaceous pelagic limestones (Umbrian Appennines, Italy, and Betic Cordillera, Southern Spain). Micropaleonotology, 36(4): 297-330.

Kuhnt, W., Geroch, S., Kaminski, M. A., Moullade, M. \& Neagu, T. 1992. Upper Cretaceous abyssal claystones in the North Atlantic and Western Tethys: current status of biostratigraphical correlation using agglutinated foraminifers and palaeoceanographic events. Cretaceous Research, 13: 467-478.

Kuhnt, W. \& Kaminski, M. A. 1997. Cenomanian to Lower Eocene deep-water agglutinated foraminifera from the Zumaya section, Northern Spain. Annales Societatis Geologorum Poloniae, 67: 257-270.

Kuhnt, W., Kaminski, M. A. \& Moullade, M. 1989. Late Cretaceous deep-water agglutinated foraminiferal assemblages from the North Atlantic and its marginal seas. Geologische Rundschau, 78(3): 11211140.

Megson, J. B. 1987. The evolution of the Rockall Trough and implications for the Faeroe-Shetland trough. In Brooks, J. \& Glennie, K. (Eds), Petroleum Geology of North West Europe: Proceedings of the 3rd Conference. Graham \& Trotman, London; 653-665.

Moullade, M., Kuhnt, W. \& Thurow, J. 1988. Agglutinated benthic foramiminifers from Upper Cretaceous variegated clays of the North Atlantic Ocean (DSDP leg 93 and ODP leg 103). In Boillot, G., Winterer, E. L., Meyer, A. W. et al. (Eds), Proceedings of the Ocean Drilling Program, Scientific Results. 349-377.

Mudge, D. C. \& Bujak, J. P. 1996. Palaeocene biostratigraphy and sequence stratigraphy of the UK central North Sea. Marine and Petroleum Geology, 13(3): 295-312.

Mudge, D. C. \& Copestake, P. 1992. Lower Palaeogene stratigraphy of the northern North Sea. Marine and Petroleum Geology, 9: 287-301.

Mudge, D. C. \& Rashid, B. 1987. The geology of the Faeroe Basin area. In Brooks, J. \& Glennie, K. (Eds), Petroleum Geology of North West Europe; Proceedings of the $3 r d$ Conference. Graham \& Trotman, London: 751-763.

Nadin, P. A., Kusznir, N. J. \& Cheadle, M. J. 1997. Early Tertiary plume uplift of the North Sea and Faeroe-Shetland Basins. Earth and Planetary Science Letters, 148: 109-127.

Nagy, J. 1992. Environmental significance of foraminiferal morphogroups in Jurassic North Sea deltas. Palaeogeography, Palaeoclimatology, Palaeoecology, 95: 111-134.
Nagy, J., Gradstein, F. M., Kaminski, M. A. \& Holbourn, A. E., 1995. Foraminiferal morphogroups, paleoenvironments and new taxa from Jurassic to Cretaceous strata of Thakkhola, Nepal. In Kaminski, M. A., Geroch, S. \& Gasinski, M. A. (Eds), Proceedings of the Fourth International Workshop of Agglutinated Foraminifera. Grzybowski Foundation. Special Publication no. 3: 181-209.

Nagy, J., Kaminski, M. A., Johnson, K. \& Mitlehner, A. G. 1997. Foraminiferal, palynomorph, and diatom biostratigraphy and paleoenvironments of the Torsk Formation: a reference section for the Paleocene-Eocene transition in the western Barents Sea. In Hass, $\mathrm{H}$ C. \& Kaminski, M. A. (Eds), Contributions to the Micropaleontology and Paleoceanography of the Northern North Atlantic. Grzybowski Foundation. Special Publication no. 5: 15-38.

Ridd, F. M. 1981. Petroleum Geology West of the Shetlands. In Illing, L. V. \& Hobson, G. D. (Eds), Petroleum Geology of the Continental Shelf of North-West Europe. Institute of Petroleum, London. 414-425.

Ritchie, J. D., Gatliff, R. W. \& Riding, J. B., 1996. Stratigraphical Nomenclature of the UK North West Margin: 1. Pre-Tertiary Lithostratigraphy. British Geological Survey, Nottingham.

Roberts, D. G., Morton, A. C. \& Backman, J. 1984. Late Paleocene Eocene volcanic events in the northern North Atlantic Ocean. In Roberts, D. G., Schnitker, D. , Baldauf, J. G. et al. (Eds), Initial Reports of the Deep Sea Drilling Project 81: Texas A\&M University, Ocean Drilling Program: 913-923.

Schröder, C. J. 1986. Deep-water arenaceous foraminifera in the northwest Atlantic Ocean. Canadian Technical Report of Hydrography and Ocean Sciences, 71: 1-191.

Thurow, J. 1988. Cretaceous radiolarians of the North Atlantic Ocean: ODP legs 93 (site 603) and 478 (site 398). In Boillot, G., Winterer, E. L., Meyer, A. W. et al. (Eds), Proceedings of the Ocean Drilling Program, Scientific Results, 379-418.

Toumarkine, M. \& Luterbacher, H. 1985. Paleocene and Eocene planktic foraminifera. In Bolli, H. M., Saunders, J. B. \& PerchNielsen, K. (Eds), Plankton Stratigraphy Volume 1: Planktic Foraminifera, Calcareous Nannofossils and Calpionellids, Cambridge University Press, Cambridge: 87-154.

Turner, J. D. \& Scrutton, R. A. 1993. Subsidence patterns in western margin basins: evidence from the Faeroe-Shetland Basin. In Parker, J. R. (Ed.), Petroleum Geology of North West Europe; Proceedings of the 4th Conference. Geological Society, London: 975-983. 